\title{
TrkB Modulates Fear Learning and Amygdalar Synaptic Plasticity by Specific Docking Sites
}

\author{
Gabriele Musumeci, ${ }^{1 *}$ Carla Sciarretta, ${ }^{1 *}$ Antonio Rodríguez-Moreno, ${ }^{2 *}$ Mumna Al Banchaabouchi, ${ }^{1}$ \\ Vicente Negrete-Díaz, ${ }^{2}$ Marco Costanzi, ${ }^{3}$ Valeria Berno, ${ }^{1}$ Alexei V. Egorov, ${ }^{4}$ Oliver von Bohlen und Halbach, ${ }^{4}$ \\ Vincenzo Cestari, ${ }^{3,5}$ José M. Delgado-García, ${ }^{2}$ and Liliana Minichiello ${ }^{1,6}$ \\ ${ }^{1}$ Mouse Biology Unit, European Molecular Biology Laboratory, 00015 Monterotondo, Italy, ${ }^{2}$ División de Neurociencias, Universidad Pablo de Olavide, \\ 41013 Sevilla, Spain, ${ }^{3}$ Istituto di Neuroscienze, Consiglio Nazionale delle Ricerche, 00143 Rome, Italy, ${ }^{4}$ Interdisciplinary Center for Neurosciences, \\ Department of Neuroanatomy, University of Heidelberg, D-69120 Heidelberg, Germany, ${ }^{5}$ Facoltà di Scienze della Formazione, Università Lumsa, \\ 00193 Rome, Italy, and ${ }^{6}$ Centre for Neuroregeneration, University of Edinburgh, EH16 4SB Edinburgh, United Kingdom
}

Understanding the modulation of the neural circuitry of fear is clearly one of the most important aims in neurobiology. Protein phosphorylation in response to external stimuli is considered a major mechanism underlying dynamic changes in neural circuitry. TrkB (Ntrk2) neurotrophin receptor tyrosine kinase potently modulates synaptic plasticity and activates signal transduction pathways mainly through two phosphorylation sites [Y515/Shc site; Y816/PLC $\gamma$ (phospholipase $\mathrm{C} \gamma$ ) site]. To identify the molecular pathways required for fear learning and amygdalar synaptic plasticity downstream of TrkB, we used highly defined genetic mouse models carrying single point mutations at one of these two sites (Y515F or Y816F) to examine the physiological relevance of pathways activated through these sites for pavlovian fear conditioning (FC), as well as for synaptic plasticity as measured by field recordings obtained from neurons of different amygdala nuclei. We show that a Y816F point mutation impairs acquisition of FC, amygdalar synaptic plasticity, and CaMKII signaling at synapses. In contrast, a Y515F point mutation affects consolidation but not acquisition of FC to tone, and also alters AKT signaling. Thus, TrkB receptors modulate specific phases of fear learning and amygdalar synaptic plasticity through two main phosphorylation docking sites.

\section{Introduction}

Emotional fear-related disorders are among the most common human psychiatric disorders. Determining the molecular mechanisms underlying the development and manifestation of such disorders is essential. Pavlovian fear conditioning (FC), a simple form of associative learning, involves learning that certain environmental stimuli predict aversive events and is considered to be a model system to examine the neurobiological basis of learning and memory in the mammalian brain. The amygdala is central for the acquisition, storage, and expression of conditioned fear memory (Lavond et al., 1993; LeDoux, 1996; Davis, 1997; Fendt and Fanselow, 1999); it consists of different nuclei, including the lateral (LA), basolateral (BL), and basal medial (BM) nuclei, which together form the basolateral complex (BLA), and the cen-

\footnotetext{
Received April 8, 2009; revised May 15, 2009; accepted July 6, 2009.

This work was supported in part by grants from the European Union (EU) [EU Sixth Framework Programme (FP6) Project Memories Grant 037831; EU FP6 Stem Stroke Grant 037526] to L.M., Grants BFU2005-01024 and BFU200614155 from the Spanish Ministry of Education and Science to J.M.D.-G. and A.R.-M., respectively, and Deutsche Forschungsgemeinschaft Grant SFB636/A5 to 0.v.B.

${ }^{*}$ G.M., C.S., and A.R.-M. contributed equally to this work.

Correspondence should be addressed to Dr. Liliana Minichiello, EMBL Mouse Biology Unit, Via Ramarini, 32, 00015 Monterotondo, Italy. E-mail: minichiello@embl.it.

C. Sciarretta's present address: Actelion Pharmaceuticals Ltd., Gewerbestrasse 16, CH-4123 Allschwil, Switzerland.

0. von Bohlen und Halbach's present address: Institute of Anatomy and Cell Biology, Ernst Moritz Arndt University, D-17487 Greifswald, Germany.

DOI:10.1523/JNEUROSCI.1707-09.2009

Copyright $\odot 2009$ Society for Neuroscience 0270-6474/09/2910131-13\$15.00/0
}

tral nucleus (CeA) (Swanson and Petrovich, 1998). The BLA receives synaptic inputs from different sensory structures, and lesions of these structures impair pavlovian FC (Gale et al., 2004; Koo et al., 2004). Synaptic inputs to the LA from the thalamic medial geniculate nucleus and from the auditory cortex are essential for conditioning with an auditory conditioned stimulus (CS) (LeDoux et al., 1990; Romanski and LeDoux, 1992; Campeau and Davis, 1995), whereas projections from the hippocampus to the BLA support conditioning with contextual CSs (Kim and Fanselow, 1992; Phillips and LeDoux, 1992; Maren et al., 1997). FC also induces behavioral long-term potentiation (LTP) in the amygdala, and synaptic responses measured in the amygdala of a behaving rat (Rogan et al., 1997) and in amygdalar slices obtained from previously conditioned rats (McKernan and Shinnick-Gallagher, 1997) are similar. Interestingly, behavioral LTP exhibits properties common to tetanic LTP in both preparations. TrkB has been genetically shown to play an important role in hippocampal synaptic plasticity and learning (Minichiello et al., 1999; Xu et al., 2000). BDNF/NT4 binding to TrkB activates three main intracellular signaling cascades. The Ras/mitogenactivated protein kinase (MAPK) pathway and the phosphoinositide 3-kinase (PI3K) pathway are activated primarily through Shc/FRS-2 binding to Y515, whereas the calcium/calmodulin kinase pathway is activated through phospholipase $\mathrm{C} \gamma(\mathrm{PLC} \gamma)$ recruitment at Y816. We have shown that the Ras/MAPK and PLC $\gamma / \mathrm{CaMK/CREB} \mathrm{(cAMP} \mathrm{response} \mathrm{element-binding} \mathrm{protein)}$ pathways act in parallel downstream of TrkB and that the PLC $\gamma$ 
docking site is necessary for TrkB-mediated hippocampal synaptic plasticity (Minichiello et al., 2002). Moreover, a TrkB Y816F but not Y515F point mutation impairs the acquisition of an associative learning task and in vivo hippocampal LTP (Gruart et al., 2007). Experiments based on temporal changes in BDNF gene expression and the intra-amygdala infusion of a lentiviral vector expressing a dominant-negative TrkB isoform have established an essential role for TrkB in pavlovian FC acquisition (Rattiner et al., 2004). However, the molecular pathways downstream of TrkB contributing to fear learning and amygdalar synaptic plasticity were not identified. The use of genetic mouse models carrying a point mutation at either the Shc or the PLC $\gamma$ docking site of TrkB ( $t r k B^{S H C}$ or $t r k B^{P L C}$, respectively) allows examination of the physiological relevance of pathways activated through these sites during pavlovian FC. We found that in vivo, pathways activated through the TrkB/PLC $\gamma$ site modulate the acquisition of conditioned fear responses to contextual and auditory stimuli, as well as, synaptic plasticity at the lateral-basolateral (LA-BL) and the thalamic-lateral (thalamic-LA) amygdala synapses. In contrast, the TrkB/Shc site through its downstream effector(s) mainly modulates the consolidation but not acquisition of fear learning to tone and the amygdalar synaptic plasticity at the thalamic-LA synapses but not at the LA-BL synapses, indicating that TrkB Y816 and Y515 contribute to specific phases of fear learning and amygdalar synaptic plasticity.

\section{Materials and Methods}

\section{Ethics statement}

All animal procedures were conducted in accordance with the rules pertaining to animal well-being and were performed in agreement with national and international laws and policies [European Economic Community Council Directive 86/609, OJ L 358, 1, December 12, 1987; National Institutes of Health (NIH) Guide for the Care and Use of Laboratory Animals, NIH Publication No. 85-23, 1985, revised in 1995). All initiatives to minimize animal experimentation and to alleviate animal pain, suffering, and distress were taken into account.

\section{Mouse strains}

The mouse strains used in this study have been previously described (Minichiello et al., 1998, 2002); however, a summary of the strategies used and validation of the point mutations are reported in the supplemental Methods, available at www.jneurosci.org as supplemental material.

\section{Behavioral procedures \\ Fear conditioning}

Adult mice (2-4 months of age) were trained and tested in an operant chamber $(18.5 \times 18 \times 21.5 \mathrm{~cm})$ possessing aluminum sidewalls and Plexiglas rear and front walls (Coulbourn Instruments). The auditory cue (tone) emanated from a loudspeaker located in the sidewall, $15 \mathrm{~cm}$ from the floor. The activity of animals was recorded directly on a computer through a single camera located at the top of the chamber. The presentation of tone and shock stimuli in all training and testing sessions was controlled by GraphicState software (Coulbourn Instruments). The chamber was cleaned with ethanol and dried between mice after each training or testing session.

Conditioning. Mice were allowed to acclimate to the training chamber for $2 \mathrm{~min}$, and then a tone (CS) of $2800 \mathrm{~Hz}$ frequency and $85 \mathrm{~dB}$ intensity was presented for $30 \mathrm{~s}$ and coterminated in the last $2 \mathrm{~s}$ with a mild footshock $(0.5 \mathrm{~mA})$ [unconditioned stimulus (US)]. Two minutes later, another CS-US pairing was presented, and the mice were returned to their home cages $30 \mathrm{~s}$ later. To facilitate the acquisition of conditioned fear in $t r k B^{P L C /+}$ mutants, five CS-US pairings were used instead of two CS-US pairings.

Behavioral testing. To test for a conditioned fear response to context, the mice were placed in the same chamber used for the conditioning trial
$24 \mathrm{~h}$ after conditioning and allowed to explore for $4 \mathrm{~min}$ without presentation of the auditory CS or footshock. Freezing behavior, defined as complete absence of voluntary movements except for respiratory movements, was scored every $1 \mathrm{~s}$. Twenty-four hours after the contextual conditioning test, the mice were tested for cue memory by returning them to the same chamber, which was modified by the addition of various shapes and designs on the walls and a vanilla scent. Freezing behavior was scored for $2 \mathrm{~min}$ before delivery of the tone and then for $2 \mathrm{~min}$ in the presence of a continuous auditory cue. Freezing behavior was measured with an automated system whereby continuous video data were analyzed with the aid of Freeze-frame software (Coulbourn Instruments). The software measures the variance in pixel intensity across successive video frames (taken at $1 \mathrm{~Hz}$ ) and computes its SD. A threshold is then applied to the data to yield a percentage freezing score. Two-way ANOVA tests (with genotype as a between-subjects factor and context or tone tests as a within-subject factor) were used for statistical analysis with $p<0.05$ set as the criterion for statistical significance. Post hoc group comparisons were performed with Fisher's LSD test.

\section{Radial maze}

The radial maze test was performed essentially as described previously (Minichiello et al., 1999). Briefly, adult male mice (3-6 months of age) were singly housed with water provided ad libitum and gradually reduced to $85 \%$ of their free-feeding body weight, which was maintained for the duration of the experiment by providing the mice with a premeasured amount of chow each day. The maze was constructed from gray plastic and was comprised of eight identical arms radiating $37 \mathrm{~cm}$ from a central starting platform (perimeter was $7 \times 8 \mathrm{~cm}$ ). At the end of each arm $20 \mathrm{mg}$ of food pellets was placed in a cup. All arms were baited only once and at the beginning of each daily session. Animals received one trial per day for 10 consecutive training days. Each daily trial terminated when 8 correct choices were made (maximum 15 choices) or 15 min elapsed. An arm choice was defined as placement of all paws on a maze arm. An error was scored when the mouse entered a previously explored arm. The percentage of errors made over 15 trials, the number of correct arm choices in the first 8 trials, and the occurrence of first error were considered. For statistical analysis, mean values were compared using a two-way ANOVA with the factors genotype ( 2 levels $=$ mutants and controls) and learning $(10$ levels $=$ training days), in which the numbers of correct arm choices out of the first 8 trials, the percentages of errors out of 15 trials, or the occurrences of the first error on each training day were compared. Individual between-group comparisons, when appropriate, were performed using post hoc tests (Duncan multiple-range test).

\section{Electrophysiology}

Coronal slices (400 $\mu \mathrm{m}$ thick) containing the amygdala were prepared and maintained using standard procedures [artificial CSF (ACSF) medium: $124 \mathrm{~mm} \mathrm{NaCl}, 3 \mathrm{~mm} \mathrm{KCl}, 1.25 \mathrm{~mm} \mathrm{KH}_{2} \mathrm{PO}_{4}, 2 \mathrm{~mm} \mathrm{MgSO}_{4}, 26 \mathrm{~mm}$ $\mathrm{NaHCO}_{3}, 1.8 \mathrm{~mm} \mathrm{CaCl}_{2}$, and $10 \mathrm{~mm}$ glucose; temperature, $28^{\circ} \mathrm{C}$; submerged recording). To evoke field EPSPs (fEPSPs), electric pulses were applied by a bipolar electrode placed either in the LA nucleus near the BL nucleus, in which recording glass electrodes were located, or in the ventral striatum, just medial to the LA, to activate fibers originating, at least in part, in the auditory thalamus. The recording glass electrodes were located in the LA nucleus (Weisskopf et al., 1999). Synaptic field potentials were elicited at a frequency of $0.1 \mathrm{~Hz}$. The slope of the recorded field was calculated and used as a measurement of synaptic strength. LTP was induced with a theta-burst stimulation (TBS) of 10 bursts of four pulses each $(100 \mathrm{~Hz}, 100 \mathrm{~ms}$ duration, $200 \mathrm{~ms}$ interburst interval) with the same strength as the test stimulus. This TBS was repeated three times at intervals of 10 s. Alternatively, LTP was induced with a tetanus of $3 \times 30$ pulses $(100 \mathrm{~Hz}, 100 \mathrm{~ms}$ duration, at intervals of $10 \mathrm{~s})$ with the same strength as the test stimulus. Strong tetanic stimulation consisted of three series of 100 pulses $(100 \mathrm{~Hz})$ with pulse lengths of $100 \mathrm{~ms}$ and delivered at intervals of $5 \mathrm{~min}$. Poststimulation recordings were continued for $60 \mathrm{~min}$ for early LTP (E-LTP) and for $180 \mathrm{~min}$ for late LTP (L-LTP). E-LTP or L-LTP was considered successfully induced when the average of the fEPSP slope size (measured at 55-60 min or 175-180 min, respectively, 

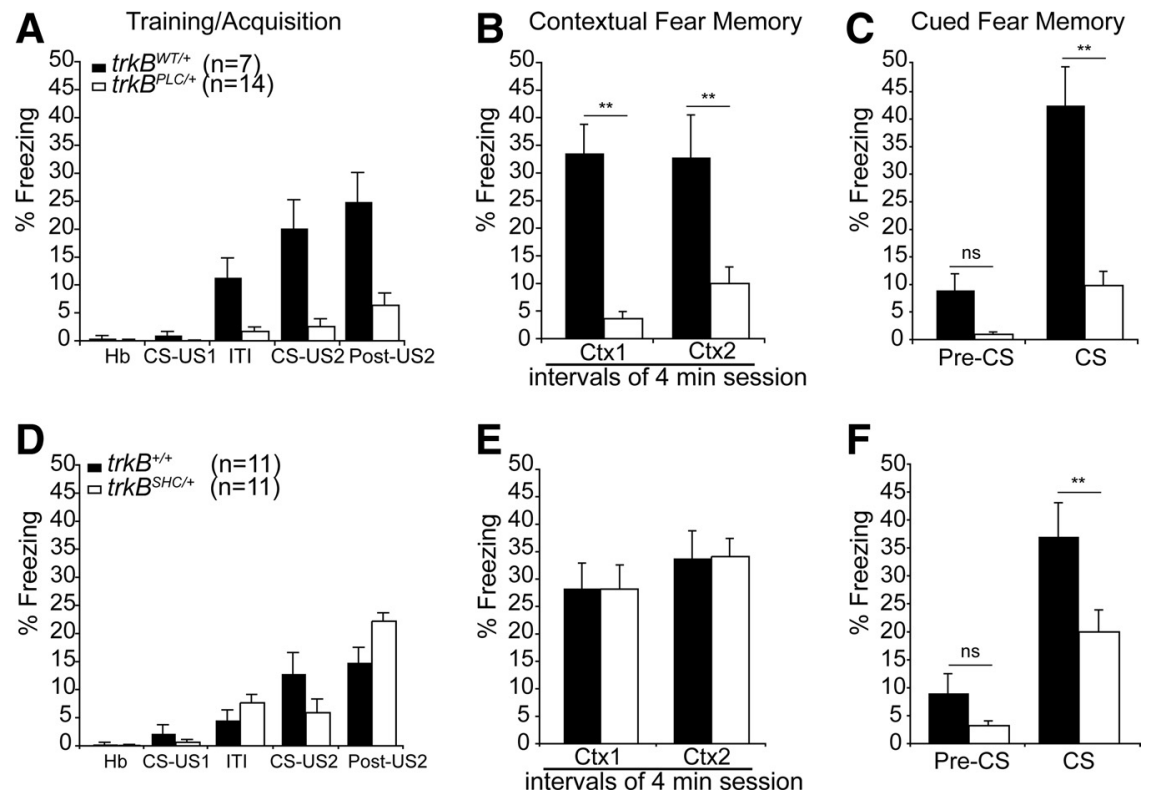

Figure 1. Associative CS-US pairing is impaired in $\operatorname{trk} B^{P L C /+}$ mutants but normal in $t r k B^{S H C /+}$ mutants. $A$, The percentage of freezing of control (trkB $\left.{ }^{W T /+}\right)$ and mutant $\left(\operatorname{trk} B^{P L C /+}\right)$ mice from a typical training trial. Whereas the control mice $\left(\operatorname{trk} B^{W T /+}\right)$ showed normal acquisition during the training phase, the $t r k B^{P L C /+}$ mutants showed impaired or highly reduced CS-US association (ANOVA; $p<0.001) . B, C$, The control (trkB ${ }^{W T /+}$ ) and the mutant (trkB $B^{P L C /+}$ ) group of mice were tested $24 \mathrm{~h}$ later for contextual fear conditioning $(\boldsymbol{B})$ followed by cued fear conditioning $(\boldsymbol{C})$. $\boldsymbol{D}$, Freezing of $\operatorname{trk} B^{5 \mathrm{HC} /+}$ mutants during the acquisition phase was similar to that of control mice $\left(\operatorname{trk} B^{+/+}\right) . \boldsymbol{E}, \boldsymbol{F}$, Twenty-four hours after conditioning, both groups of mice were tested first for contextual fear conditioning $(\boldsymbol{E})$ and then for cued fear conditioning $(\boldsymbol{F})$. $n=$ number of mice per group. Bars represent mean \pm SEM. ${ }^{*}$ Statistically significant (see Results), $p<0.001 ; \mathrm{ns}$, not significant; ITI, intertrial interval; $\mathrm{Hb}$, habituation.

after TBS or tetanus) showed an increase of at least $20 \%$ above baseline $(100 \%)$ values. Routinely, paired-pulse facilitation (PPF) was tested at intervals of 10, 30, 40, 50, 100, and $200 \mathrm{~ms}$. All measurements were performed and analyzed in a strictly blind manner. The genotypes of the animals were revealed only after the electrophysiological experiments and their evaluation were complete. To analyze the functionality of the NMDA and AMPA/kainate receptors, fEPSPs were recorded initially for $20 \mathrm{~min}$ (baseline recording) and then after the addition of 6-cyano-7-nitroquinoxaline-2,3-dione (CNQX) in low- $\mathrm{Mg}^{2+}(0.5 \mathrm{~mm})$ ACSF applied to the bath solution. After $15 \mathrm{~min}$, DL-2-amino-5phosphonovalerate (AP-5) (50 mM) together with CNQX was applied for $30 \mathrm{~min}$ to the same slice in low- $\mathrm{Mg}^{2+}$ ACSF. Afterward, normal ACSF was used for washout. The results were analyzed for statistical significance using two-tailed, unpaired Student's $t$ tests.

\section{Anatomical/biochemical experiments \\ Conditioning}

Adult mice (2-4 months) were trained in a polymodal operant chamber (see above). Before training, they were allowed to acclimate for $2 \mathrm{~min}$, and then two or five conditioning trials were applied consisting of a $30 \mathrm{~s}$, $2800 \mathrm{~Hz}$, and $85 \mathrm{~dB}$ tone that coterminated with a $2 \mathrm{~s}, 0.5 \mathrm{~mA}$ footshock; intertrial intervals were $120 \mathrm{~s}$. Mice were returned to their home cages and $45 \mathrm{~min}$ later they were either immediately killed (when analyzed for pAKT and pMAPKs) or first tested for both context ( $3 \mathrm{~min}$ ) and cue (2 min tone) and then killed immediately thereafter (when analyzed for pCaMKII). Brains were taken for histological and biochemical analysis. Control animals were not exposed to tones or shocks.

\section{Brain sample collection}

For biochemical analysis, mice were killed by cervical dislocation, and the brains were removed from the skull and (without olfactory bulbs) positioned in a cold matrix with which $3 \mathrm{~mm}$ coronal slices were collected, followed by the isolation of amygdala nuclei from the basolateral portions of the slice. Samples were frozen in liquid nitrogen and stored at $-80^{\circ} \mathrm{C}$ until use.

\section{Biochemistry}

Brain samples were homogenized using micropestles (Eppendorf) and lysed on ice in NP-40 complete lysis buffer [10\% glycerol, $50 \mathrm{~mm} \mathrm{HEPES} / \mathrm{NaOH}$ ( $\mathrm{pH} 8.0$ ), $100 \mathrm{~mm} \mathrm{KCl}$, 1\% NP-40, 2 mм EDTA, 2 mм DTT, $10 \mathrm{~mm}$ $\mathrm{NaF}, 1 \mathrm{~mm} \mathrm{Na} \mathrm{VO}_{4}, 1 \mathrm{~mm} \mathrm{NaPP}, 5$ mм benzamidine, $10 \mu \mathrm{g} / \mathrm{ml}$ leupeptine, $14 \mu \mathrm{g} / \mathrm{ml}$ aprotinin]. Cellular debris were removed by centrifugation at $16,000 \mathrm{rpm}$ for $20 \mathrm{~min}$ at $4^{\circ} \mathrm{C}$. Cortical neurons were washed twice with cold PBS and then lysed on ice for 15 min with $0.6 \mathrm{ml}$ of $1 \%$ Triton X-100 lysis buffer [50 mm Tris ( $\mathrm{pH} 7.5$ ), $120 \mathrm{~mm} \mathrm{NaCl}$, $10 \mathrm{~mm} \mathrm{NaF}, 1 \mathrm{~mm} \mathrm{Na}_{3} \mathrm{VO}_{4}$, and protease inhibitors as described above]. Insoluble material was removed from the protein extracts by centrifugation at $13,000 \mathrm{rpm}$ for $15 \mathrm{~min}$ at $4^{\circ} \mathrm{C}$. The protein content in supernatant fractions was quantified (Bio-Rad $\mathrm{D}_{\mathrm{C}}$ protein assay kit) and aliquots were frozen in liquid nitrogen and stored at $-80^{\circ} \mathrm{C}$ until use. Protein levels were analyzed by Western blot as previously described (Minichiello et al., 1998, and supplemental Methods, available at www.jneurosci.org as supplemental material). The antibodies (Abs) used were anti-pAKT [Cell Signaling, catalog no. (Cat.) 9271; 1:1000], anti-AKT (Cell Signaling, Cat. 9272; 1:1000), anti-pMAPK (New England Biolabs, clone E10; 1:2000), and anti-ERK1 (extracellular signal-regulated kinase 1) (Zymed 13$8600 ; 1: 3000)$. The relative levels of proteins were quantified as described in the supplemental Methods, available at www.jneurosci.org as supplemental material.

\section{Synaptosome preparation}

Brain samples were processed according to the synaptosomal preparation described by Nagy and Delgado-Escueta (1984). Briefly, the amygdalae of each animal were homogenized in $2 \mathrm{ml}$ of buffer $[0.32 \mathrm{M}$ sucrose, $1 \mathrm{~mm}$ EDTA, $1 \mathrm{mg} / \mathrm{ml} \mathrm{BSA}, 5 \mathrm{~mm}$ HEPES (pH 7.4, reached using $1 \mathrm{M} \mathrm{NaOH}$ )] by use of a Dounce homogenizer (10 strokes and $520 \mathrm{rpm}$ ). Thirty microliters of crude homogenate was removed and served as the whole-tissue lysate sample and the remaining homogenate was centrifuged for $10 \mathrm{~min}$ at $3000 \times g$. The supernatants were subsequently centrifuged for $12 \mathrm{~min}$ at $14,000 \times g$ and resultant pellets were resuspended in $220 \mu \mathrm{l}$ of Krebs-Ringer buffer [ $140 \mathrm{~mm} \mathrm{NaCl}, 5 \mathrm{~mm} \mathrm{KCl}, 10 \mathrm{~mm}$ HEPES, 1 mм EDTA, 5 mm glucose (pH 7.4, reached using $1 \mathrm{~m} \mathrm{NaOH}$ )] and $180 \mu \mathrm{l}$ of Percoll (Sigma-Aldrich, P7828). Samples were then centrifuged for $2 \mathrm{~min}$ at $14,000 \times \mathrm{g}$. The synaptosome fraction of the gradient was removed, washed twice with $500 \mu \mathrm{l}$ of Krebs-Ringer buffer, and centrifuged for $30 \mathrm{~s}$ at $14,000 \times \mathrm{g}$. The final pellets were resuspended in 40 $\mu \mathrm{l}$ of Krebs-Ringer buffer. All steps of the procedure were performed at $4^{\circ} \mathrm{C}$ using ice-cold buffers. Samples were separated by SDS-PAGE using 10\% acrylamide and transferred onto nitrocellulose membranes. The blots were probed using anti-pCaMKII (ProMega, V1111; 1:1000), anti-CaMKII (Santa Cruz, H-300 s.c.-13082; 1:1000), anti-synapsin I/II (Synaptic Systems, 106 002; 1:5000), and anti-PSD95 (Upstate Biotechnology, cloneK28/43 05-494; 1:200,000). The secondary antibodies used were a goat anti-rabbit HRP-conjugated (Jackson ImmunoResearch, 115-035003; 1:5000) and a goat anti-mouse HRP-conjugated (Jackson ImmunoResearch 115-035-146; 1:5000) IgG.

\section{Histology}

Mice were anesthetized with avertin (20 mg/kg, i.p.) and transcardially perfused with ice-cold PBS followed by $3 \%$ paraformaldehyde (PFA) in $0.1 \mathrm{M}$ phosphate buffer (PB). The perfusion was performed using a peristaltic pump and a flow rate of $1 \mathrm{ml} / \mathrm{min}$. The brains were removed from the skull and postfixed in 3\% PFA-PB overnight at 

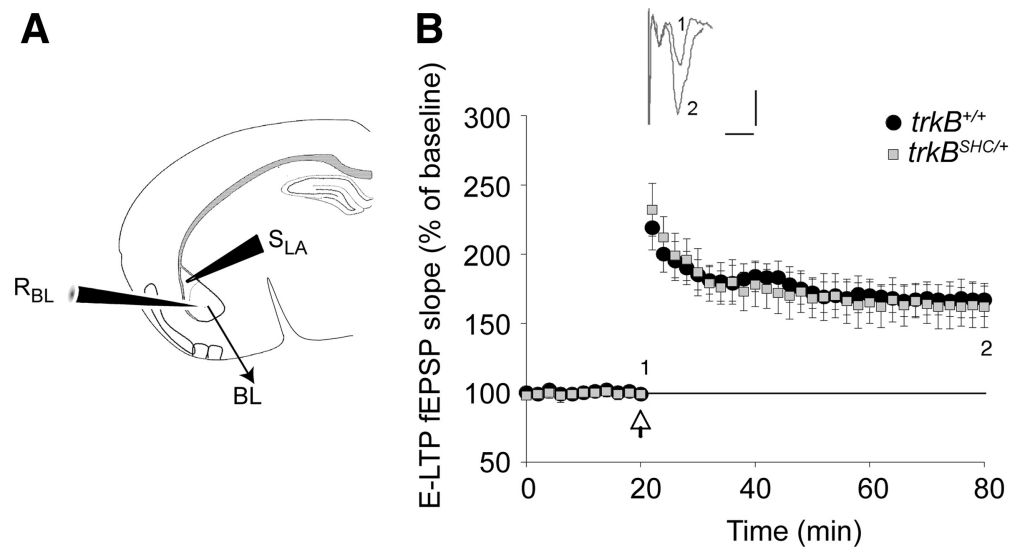

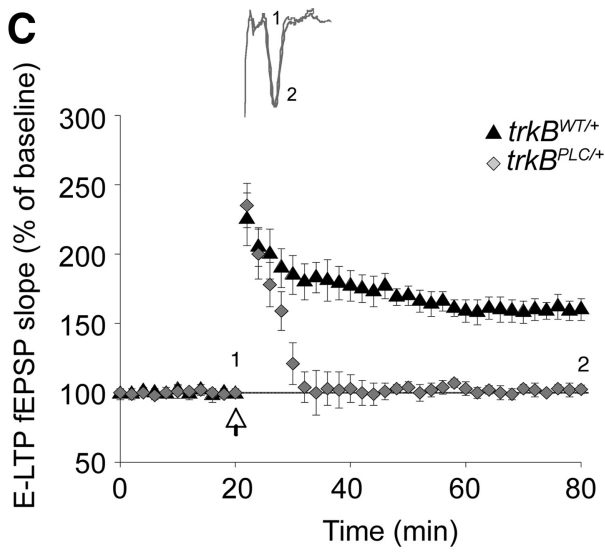

Figure 2. Synaptic plasticity at the LA-BL synapses is impaired in $t r k B^{P L C /+}$ but not in trkB ${ }^{S H C /+}$ mutants. $\boldsymbol{A}$, Schematic representation of stimulating and recording electrodes. $\boldsymbol{B}, \boldsymbol{C}$, Symbols represent average responses plotted every $2 \mathrm{~min}$. After $20 \mathrm{~min}$ of control recordings, an HFS train was presented, marked by the arrow. Data are represented as the mean $\pm S E M$. $S_{L A}$, $S$ timulating (lateral amygdala); $\mathrm{R}_{\mathrm{BL}}$, recording (basolateral amygdala). $\boldsymbol{B}$, Normal E-LTP in trkB ${ }^{S H C /+}$ point mutant mice compared with control trkB ${ }^{+/+}$mice $(p>0.1)$. The number of slices analyzed were five for control mice (trkB ${ }^{+/+}$) and eight for trkB $B^{S H C /+}$ mice. C, E-LTP is abolished in trkB ${ }^{P L C /+}$ mice. The difference between trkB ${ }^{P L C /+}$ mutants and control mice (trkB ${ }^{W T /+}$ ) is statistically significant $(p<0.01)$. Traces show EPSP before (1) and $60 \mathrm{~min}$ after (2) LTP protocol was applied. Calibration: $5 \mathrm{~ms}, 0.5 \mathrm{mV}$. The number of slices analyzed were 6 for control mice (trkB ${ }^{W T /+}$ ) and 10 for trkB $B^{P L /}+$ mice.

$4^{\circ} \mathrm{C}$, cryoprotected in $30 \%$ sucrose- $\mathrm{PB}$ at $4^{\circ} \mathrm{C}$ for $48 \mathrm{~h}$, and then frozen in OCT Tissue Tek compound (Bayer) by immersion in liquid nitrogen-cooled isopentane. Immunohistochemistry was performed as described by Minichiello et al. (1999). Briefly, 30- $\mu$ m-thick coronal freefloating sections through the amygdala were obtained using a cryostat. Selected sections were immunostained using an anti-pMAPK Ab (Cell Signaling, 9106; 1:4000). More details of the tissue stainings are reported in the supplemental Methods, available at www.jneurosci.org as supplemental material.

\section{Neuronal cultures}

Cerebral cortices were dissected from embryonic day 15.5 mouse embryos generated from breedings of control mice or trkB point mutants. Cortical neurons were dissociated and plated onto poly-L-lysine hydrobromide (Sigma) in the presence of $10 \%$ heat-inactivated horse serum for $3 \mathrm{~h}$. Cultures were maintained for $16 \mathrm{~h}$ before ligand stimulation in $\mathrm{N} 2-\mathrm{MEM}$ at $37^{\circ} \mathrm{C}$ in $5 \% \mathrm{pCO}_{2}$. Cells were stimulated with 5 or $50 \mathrm{ng} / \mathrm{ml}$ of purified recombinant BDNF (Genentech and Regeneron Pharmaceuticals) as described previously (Minichiello et al., 2002).

\section{Imaging}

\section{Immunofluorescence}

Sections were imaged on a Leica TCS SP5 confocal microscope using a Leica $40 \times / 1.4$ NA Plan Apochromat oil objective.

\section{Immunohistochemistry}

Imaging of stained sections was performed using a Leica bright-field DMRA microscope.

\section{Results}

\section{Mouse models}

To determine which site-specific activated pathway(s) downstream of the TrkB receptor contributes to fear-related synaptic plasticity in the amygdala, we used genetic mouse models carrying a point mutation at the Shc or the PLC $\gamma$ docking site $\left(t r k B^{S H C}\right.$ or $\operatorname{trk} B^{P L C}$ ) of the TrkB receptor [these two mouse strains were previously described by Minichiello et al. (1998, 2002); also see supplemental Methods, available at www.jneurosci.org as supplemental material]. To avoid concerns about developmental abnormalities, we focused mainly on heterozygous point mutants of both strains, as they do not display relevant developmental phenotypes (supplemental Methods and Figs. S1, S2, available at www.jneurosci.org as supplemental material) and thus allow for behavioral analysis.

\section{Differential regulation of fear-related learning by the PLC $\gamma$ and Shc site in TrkB}

Analysis of behavior in the open-field test and elevated plus maze revealed no significant difference in terms of locomotor, nonlocomotor, grooming and object exploration activity, and anxiety-like behavior between all groups of mice analyzed $\left[\operatorname{trkB} B^{+/+}, \operatorname{trk} B^{S H C /+}, \operatorname{trkB}\right.$ wild-type knock-in $\left(\operatorname{trkB}{ }^{W T /+}\right)$, and trkB ${ }^{P L C /+}$ mice] (supplemental Fig. S3, available at www. jneurosci.org as supplemental material). We then used an associative learning paradigm (classical fear conditioning) to assess aversive learning and memory. On the conditioning day, mice were given two pairings of a tone (CS) and a footshock (US) (Fig. $1 A, D$ ). The $t r k B^{P L C /+}$ mice showed impaired associative learning of the CS-US pairing during the training phase compared with the control mice $\left(\operatorname{trk} B^{W T /+}\right)$ (Fig. $\left.1 A\right)$, as evidenced by a similar amount of freezing to the second CS presentation $(\mathrm{CS} 2)$ as to the first CS presentation $(\mathrm{CS} 1)\left(\mathrm{CS} 2 \mathrm{vs} \mathrm{CS} 1 ; F_{(4.83)}=\right.$ $2.5 ; p=0.29)$. In contrast, the control mice $\left(\operatorname{trk} B^{W T /+}\right)$ showed normal acquisition during the training phase $\left(\mathrm{CS} 2 \mathrm{vs} \mathrm{CS} 1 ; F_{(6.83)}=\right.$ $19.1 ; p<0.001)$ and an overall significantly higher number of freezing responses compared with the $\operatorname{trk} B^{P L C /+}$ mice $\left(F_{(2.648)}=\right.$ 9.398; $p<0.001)$. At $24 \mathrm{~h}$, control $\left(\operatorname{trk} B^{W T /+}\right)$ and mutant (trk$B^{P L C /+}$ ) mice were tested for contextual fear conditioning. As expected, the $t r k B^{P L C /+}$ mice were unable to recognize the context and displayed almost no freezing responses compared with their controls $\left(\right.$ trkB $B^{W T /+}$ mice $)\left(F_{(7.827)}=26.336 ; p<0.001\right)$ (Fig. $\left.1 B\right)$. Twenty-four hours after the test of contextual conditioning, the mice were placed in a novel chamber for $2 \mathrm{~min}$ before the tone was delivered for $2 \mathrm{~min}$. Whereas the control mice showed a significantly higher number of freezing responses at the tone onset $\left(C S\right.$ onset vs pre-CS; $\left.F_{(10.40)}=33.54 ; p<0.001\right)$, the $t r k B^{P L C /+}$ mutants elicited a very low number of freezing responses (CS onset vs pre-CS; $\left.F_{(7.359)}=8.89 ; p=0.02\right)$ (Fig. $1 C$ ) and significantly less compared with control mice $\left(F_{(6.373)}=20.31 ; p<\right.$ $0.001)$. However, similar amounts of freezing were observed between the $\operatorname{trk} B^{P L C /+}$ mutants and control mice before CS onset $\left(\right.$ trkB $B^{P L C /+}$ pre-CS vs $t r k B^{W T /+}$ pre-CS; $\left.F_{(9.013)}=7.98 ; p=0.08\right)$. 

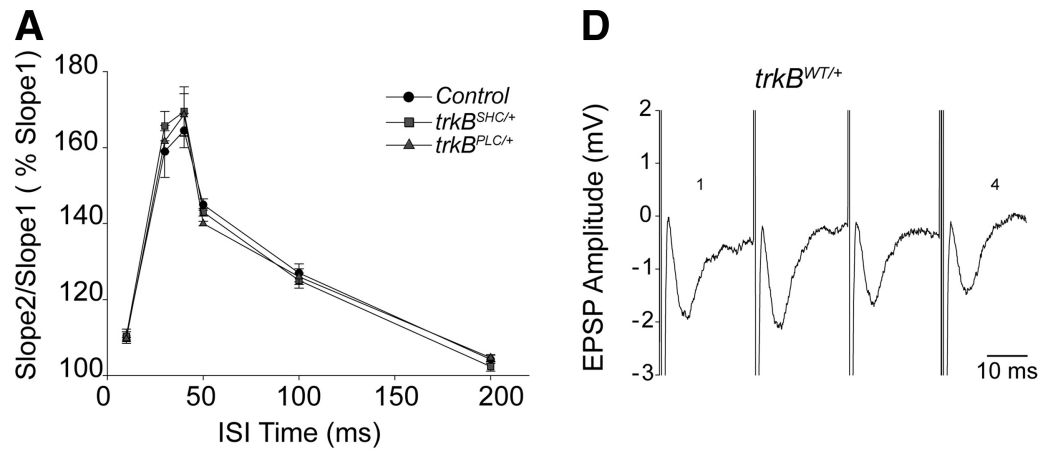

B
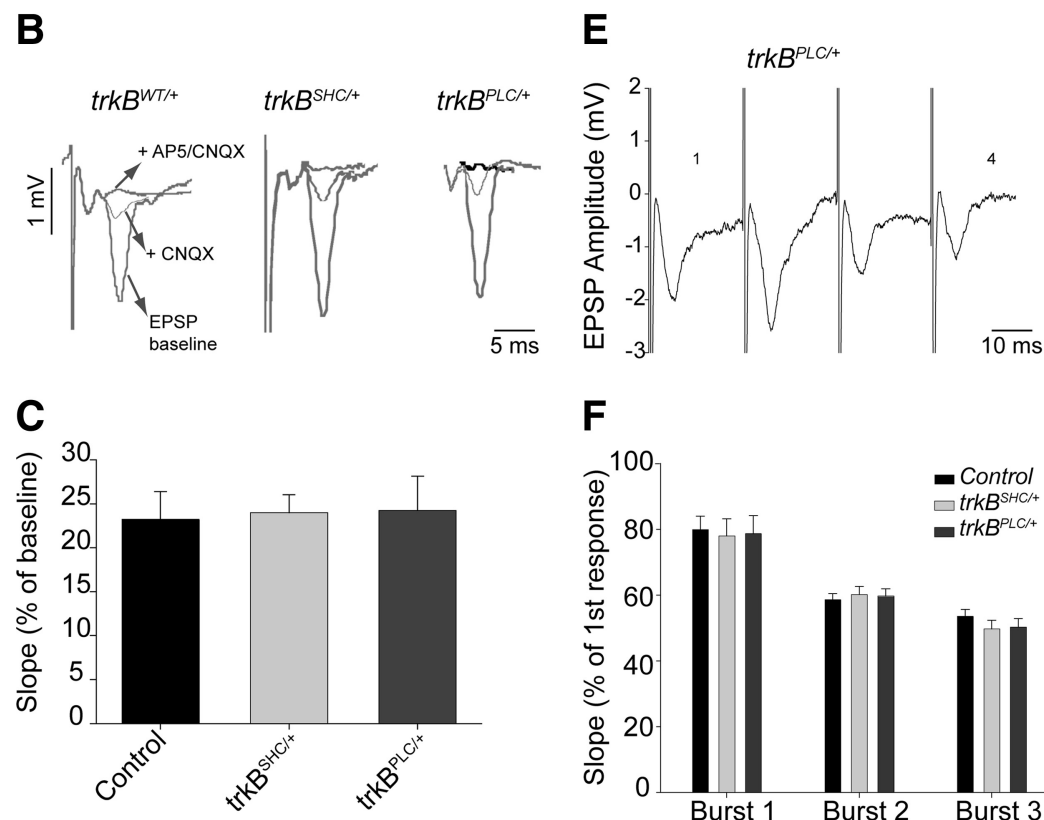

$\mathbf{F}$

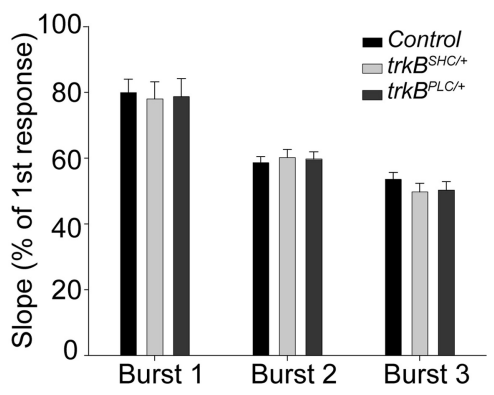

Figure 3. Normal basal synaptic transmission at $B L-L A$ synapses of $t r k B^{P L C /+}$ mice. $A, P P F$ was measured to determine whether this aspect of synaptic transmission was normal in $t r k B^{P L C /+}$ mice compared with controls. The percentages denote the ratio of the second fEPSP slope to the first fEPSP slope. PPF was tested at 10, 30, 40,50, 100, and $200 \mathrm{~ms}$ ISIs. There was no significant difference between genotypes. Error bars correspond to the SEM. $\boldsymbol{B}$, AMPA/kainate receptor (CNQX) and NMDA receptor (AP-5) antagonists were used to analyze whether NMDA and AMPA/kainate receptors are functional in $t r k B^{P L C /+}$ mice. Shown are single traces of extracellular recordings for $t r k B^{W T /+}$, $t r k B^{P L C /+}$, and $t r k B^{S H C /+}$ genotypes. Arrows indicate baseline EPSP 15 min after CNQX application or 15 min after AP-5-plus-CNQX application. C, Summary data for all pharmacological experiments. Plotted is the ratio of the EPSP slope $15 \mathrm{~min}$ after CNQX application in comparison with baseline recordings. There was no statistically significant difference between genotypes ( $p>0.1$; Student's $t$ test). $\boldsymbol{D}, \boldsymbol{E}$, Synaptic fatigue during high-frequency stimulation. Single traces collected during theta-burst stimulation from $t r k B^{W T /+}$ control animal $(\boldsymbol{D})$ and from $t r k B^{P L C /+}$ mutant mouse $(\boldsymbol{E})$. The response to the fourth stimulus (indicated by 4 ) was compared with the response to the first one (indicated by 1 ). $\boldsymbol{F}$, Data corresponding to controls and to $t r k B^{S H C /+}$ and $t r k B^{P L C /+}$ mutants during high-frequency stimulation. Plotted is the ratio of the fourth to the first response in a burst of four stimuli during theta-burst stimulation. For LTP induction, three theta bursts were applied, and data for all three are shown. Synaptic fatigue can be observed in all genotypes, and there is no statistically significant difference between control, trkB ${ }^{S H C /+}$, and trkB ${ }^{P L C /+}$ mice ( $p>0.1$; Student's $t$ test).

In contrast, the $t r k B^{S H C /+}$ mutants showed normal acquisition during the training phase when compared with the control mice $\left(\operatorname{trkB} B^{+/+}\right)$, and no significant difference was observed between the two groups $\left(F_{(3.085)}=0.369 ; p=0.081\right)$ (Fig. 1D). Twentyfour hours after conditioning the $t r k B^{S H C /+}$ mutants together with the control mice were tested first for contextual fear conditioning. Both groups of mice were able to recognize the context and displayed comparable levels of freezing $(p>0.05)$ (Fig. $1 E$ ). However, when later tested for auditory fear conditioning, whereas significantly increased levels of freezing elicited by the auditory conditioned stimulus were observed in the control group (CS onset vs pre-CS; $F_{(11.28)}=27.99 ; p<0.001$ ), the trkB $B^{S H C /+}$ mutants showed a significantly reduced number of freezing responses compared with the control mice $\left(F_{(11.28)}=16.80 ; p=0.005\right)$ (Fig. 1F). Similar amounts of freezing were observed for the $\operatorname{trkB} B^{S H C /+} \mathrm{mu}-$ tants and control mice before CS onset $\left(\right.$ trkB $B^{S H C /+}$ pre-CS vs $\operatorname{trkB}{ }^{+/+}$pre-CS; $\left.F_{(11.28)}=5.79 ; p=0.3\right)$. To verify whether the deficits observed at $48 \mathrm{~h}$ after conditioning in the $\operatorname{trk} B^{S H C /+}$ point mutant mice were specifically related to consolidation processes, new groups of mice ( $t r k B^{S H C /+}$ and control) were tested for cued fear conditioning $30 \mathrm{~min}$ after training. In this test, the $\operatorname{trkB} B^{S H C /+}$ mutants showed freezing responses $(44.5 \pm 3 \% ; n=5)$ to the cue similar to those of the control group $(39 \pm 10 \% ; n=4)(p=0.5 ; t$ test $)$, and similar levels of freezing were displayed by the two groups before the onset of the CS ( $p=0.3$ ) (supplemental Fig. $S 4 D, E$, available at www.jneurosci. org as supplemental material), suggesting that the deficit observed $48 \mathrm{~h}$ after training is caused by a failure in the $t r k B^{S H C /+}$ mutants to consolidate the auditory fear-related memory. A similar test was performed with the $\operatorname{trk} B^{P L C /+}$ and control mice. As shown in supplemental Figure $\mathrm{S} 4 \mathrm{~F}-\mathrm{H}$, available at www.jneurosci.org as supplemental material, $t r k B^{P L C /+}$ mice exhibited a deficit in freezing responses to both context and cue compared with control mice $30 \mathrm{~min}$ after training $(p=0.05$ and $p<0.0001$, respectively; $t$ test), suggesting that the reduced level of conditioned fear responses seen at 24 and $48 \mathrm{~h}$ is caused mainly by an impaired acquisition. To directly assess memory consolidation in the $\operatorname{trk} B^{P L C /+}$ mice, we attempted to facilitate the acquisition phase by increasing the number of CS-US pairings to five during training. We found that with this protocol trkB $B^{P L C /+}$ mice showed improved acquisition, which was comparable with that of control mice ( $p=0.5$ ) (supplemental Fig. S5A, available at www.jneurosci.org as supplemental material), as well as improved memory consolidation when tested $24 \mathrm{~h}$ later for contextual fear conditioning and $48 \mathrm{~h}$ later for cued fear conditioning $(p=0.3$ and $p=0.2$ for CTX1 and CTX2, respectively, compared with controls) (supplemental Fig. S5B, available at www.jneurosci.org as supplemental material) and CS onset $(p=0.4$ compared with controls) (supplemental Fig. S5C, available at www.jneurosci. org as supplemental material).

\section{Pain sensitivity is normal in both $\operatorname{trkB}^{P L C /+}$ and $\operatorname{trkB} B^{S H C /+}$ point mutants}

To rule out the possibility that differences in freezing behavior were attributable to altered pain sensitivity in the $t r k B$ point mutant mice, we measured the current threshold of flinch movements, vocalization, and jump movements caused by the nociceptive shock. We also checked for fecal boli and micturition 
A

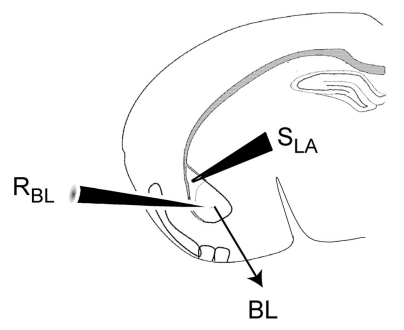

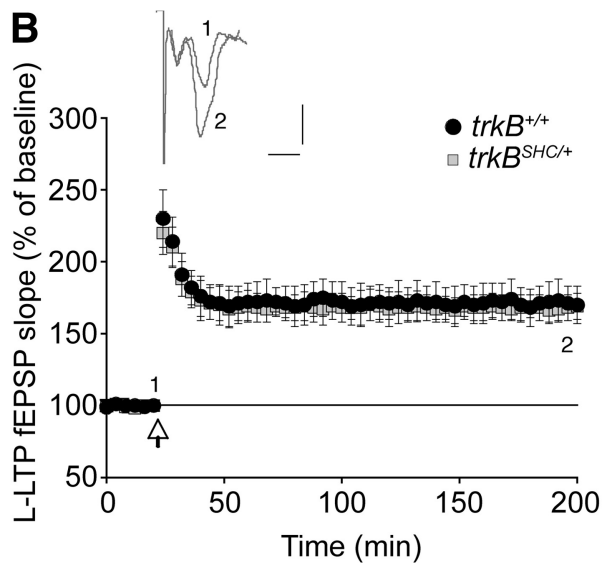

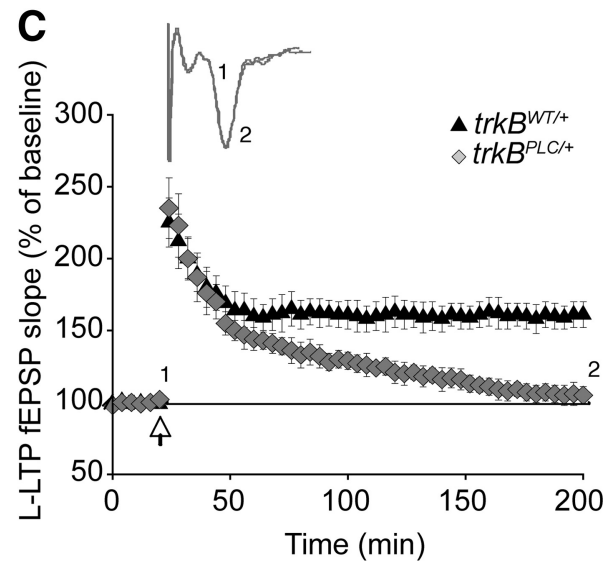

Figure 4. Long-lasting LTP is strongly impaired in BL-LA synapses of trkB $B^{P L C /+}$ mutants. $A$, Schematic representation of stimulating and recording electrodes. $S_{L A}$, Stimulating (lateral amygdala); $\mathrm{R}_{\mathrm{BL}}$, recording (basolateral amygdala). $\boldsymbol{B}, \boldsymbol{C}$, Slope size of fEPSP recordings before and after the TBS stimulus was plotted. Symbols represent average responses plotted every 4 min. After 20 min of control recordings, HFSs were presented at the time marked by the arrow. Data are represented as the mean \pm SEM. $B$, L-LTP is not significantly different in trkB ${ }^{\text {SHC/+ }}$ mutants compared with controls $\left(\right.$ trkB $\left.{ }^{+/+}\right)(p>0.1)$. The number of slices was 5 for control mice (trkB $\left.{ }^{+/+}\right)$and 10 for trkB $B^{\text {SHC/+ }}$ mice. C, L-LTP is abolished in trkB ${ }^{P L /+}$ mice. The difference between trkB ${ }^{P L C /+}$ mutants and control mice $\left(t r k B^{W T /+}\right)$ was statistically significant $(p<0.01)$. Traces show EPSP before (1) and $180 \mathrm{~min}$ after (2) LTP protocol was applied. Calibration: $5 \mathrm{~ms}, 0.5 \mathrm{mV}$. The number of slices was four for control mice $\left(\right.$ trkB $\left.B^{W T /+}\right)$ and five for $t r k B^{P L C /+}$ mice.

(supplemental Table S1, available at www.jneurosci.org as supplemental material). Using Fisher's exact probability test (two tailed), no differences in pain sensitivity were found between genotypes $\left(\operatorname{trk} B^{W T /+}\right.$ vs $\operatorname{trk} B^{P L C /+}, p=0.8 ; \operatorname{trk} B^{+/+}$vs $\operatorname{trk} B^{S H C /+}$, $p=0.9)$. Moreover, no differences were found between the control groups $\left(\operatorname{trk} B^{W T /+}\right.$ vs $\left.\operatorname{trk} B^{+/+}, p=0.54\right)$ or between the two point mutants $\left(\operatorname{trk} B^{P L C /+}\right.$ vs $\left.\operatorname{trk} B^{S H C /+}, p=0.54\right)$.

\section{trkB $B^{P L C}$ but not $t r k B^{S H C}$ phosphorylation mutants presented} impaired early LTP at the BL amygdalar synapses

To characterize the molecular basis for the impaired fear conditioning learning to both context and an auditory cue that was observed in the $\operatorname{trkB} B^{P L C /+}$ mutants, and of impaired consolidation for cued fear conditioning in the $t r k B^{S H C /+}$ mutants, we obtained field potential recordings from neurons of the BL nucleus of the amygdala by stimulating neurons in the LA nucleus in brain slices of adult mice. To prevent an underestimation of the requirements of TrkB signaling in fear learning, both homozygous and heterozygous point mutant mice were used for the in vitro electrophysiology experiments. Both types of stimulation, TBS and tetanus, produced LTP. As shown in supplemental Figure $\mathrm{S} 6 \mathrm{~A}$, available at www.jneurosci.org as supplemental material, C57BL/ 6 or $\mathrm{trkB}^{+/+}$control mice showed LTP in $91.7 \%$ of the cases ( 24 slices from nine mice) or $80 \%$ of the cases ( 5 slices from three mice), respectively; $\operatorname{trk} B^{W T /+}$ or $\operatorname{trk} B^{W T / W T}$ control mice showed LTP in $83.3 \%$ of the cases ( 6 slices from three mice) or $100 \%$ of the cases (4 slices from three mice), respectively; trkB $B^{S H C /+}$ or $t r k B^{S H C / S H C}$ mutant mice showed LTP in $87.5 \%$ of the cases ( 8 slices from three mice) or $100 \%$ of the cases ( 6 slices from three mice), respectively; whereas $t r k B^{P L C /+}$ or $t r k B^{P L C / P L C}$ mutant mice showed LTP in 10\% of the cases (10 slices from three mice) or $20 \%$ of the cases (10 slices from three mice), respectively. The magnitude of the potentiation, expressed as the mean percentage of fEPSP slope with respect to baseline (set at $100 \%)$, quantified at 55-60 min after stimulation, was $167 \pm$ $12 \%$ of baseline $(n=5)$ for the $\operatorname{trk} B^{+/+}$control mice and $162 \pm 16 \%$ of baseline $(n=8)$ for the $t r k B^{S H C /+}$ mutants (Fig. $2 B)$. Similar results were observed in $t r k B^{S H C / S H C}$ mutant slices ( $164 \pm 9 \%$ of baseline; $n=6$ ) (supplemental Fig. S6 B, available at www.jneurosci.org as supplemental material), suggesting that ablation of signaling from the Shc site of TrkB does not interfere with this form of synaptic activity. In contrast, E-LTP was abolished in $\operatorname{trk} B^{P L C /+}$ mice $(102 \pm 3 \%$ of baseline; $n=10)$ compared with control mice $\left(\operatorname{trk} B^{W /+}, 160 \pm\right.$ $8.5 \%$ of baseline; $n=6$ ) (Fig. $2 C$ ). The difference between $\operatorname{trk} B^{P L C /+}$ mutants and control mice $\left(\operatorname{trk} B^{W T /+}\right)$ was statistically significant $(p<0.01)$. Similar results were observed in trkB $B^{P L C / P L C}$ mutant slices (109 $\pm 7 \%$ of baseline; $n=10$ ) (supplemental Fig. S6B, available at www.jneurosci.org as supplemental material).

\section{Synaptic transmission in $t r k B^{P L C}$ mice is indistinguishable from that of control mice}

A number of control experiments were performed to rule out the possibility that the failure to induce LTP in the $\operatorname{trk} B^{P L C /+}$ mutants was attributable to impaired synaptic transmission at the BL synapses. First, the presynaptic fiber volley (PSFV), which is proportional to the number of presynaptic neurons recruited by stimulation, was compared with the slope of the field potential, and this comparison revealed that basal synaptic transmission was normal in $t r k B^{P L C /+}$ mutants. The EPSP slope/PSFV ratio was $1.6 \pm 0.21$ for controls, $1.6 \pm 0.3$ for $\operatorname{trk} B^{P L C /+}$ mice, and $1.5 \pm 04$ for $\operatorname{trk} B^{P L C / P L C}$. Second, using an interstimulus interval (ISI) from 10 to $200 \mathrm{~ms}$, the PPF was found to be normal in all genotypes analyzed (Fig. $3 A$ ), including the homozygous point mutants for both strains ( $t$ rkB ${ }^{P L C / P L C}, 10 \mathrm{~ms}: 108 \pm 6 ; 30$ ms: $160 \pm 8 ; 40$ ms: $168 \pm 8 ; 100$ ms: $128 \pm 8 ; 200$ ms: $105 \pm 5$. trkB ${ }^{\text {SHC/SHC }}, 10 \mathrm{~ms}: 110 \pm 8 ; 30 \mathrm{~ms}: 164 \pm 9 ; 40 \mathrm{~ms}: 164 \pm 9 ; 100$ ms: $126 \pm 7 ; 200 \mathrm{~ms}: 106 \pm 4)$. Although the induction of LTP failed in $t r k B^{P L C /+}$ mutants, all slices showed post-tetanic potentiation when the TBS or tetanus was applied (data not shown). We next tested glutamate receptor-mediated transmission by measuring the NMDA receptor component of the fEPSP under low- $\mathrm{Mg}^{2+}$ conditions (Fig. $3 B$ ). In the presence of the AMPA/ kainate receptor antagonist CNQX, amygdalar slices from all genotypes showed a comparable NMDA receptor component of the EPSP. The fEPSP slope was reduced to $24.2 \pm 3.9 \%$ (baseline $=100 \%$ ) in $t r k B^{P L C /+}$ mice, compared with $23.5 \pm$ $3.1 \%$ in $t r k B^{W T /+}$ control mice and $24 \pm 2 \%$ in $t r k B^{S H C /+}$ mutants (Fig. $3 B, C$ ). Thus, there was no statistically significant difference 

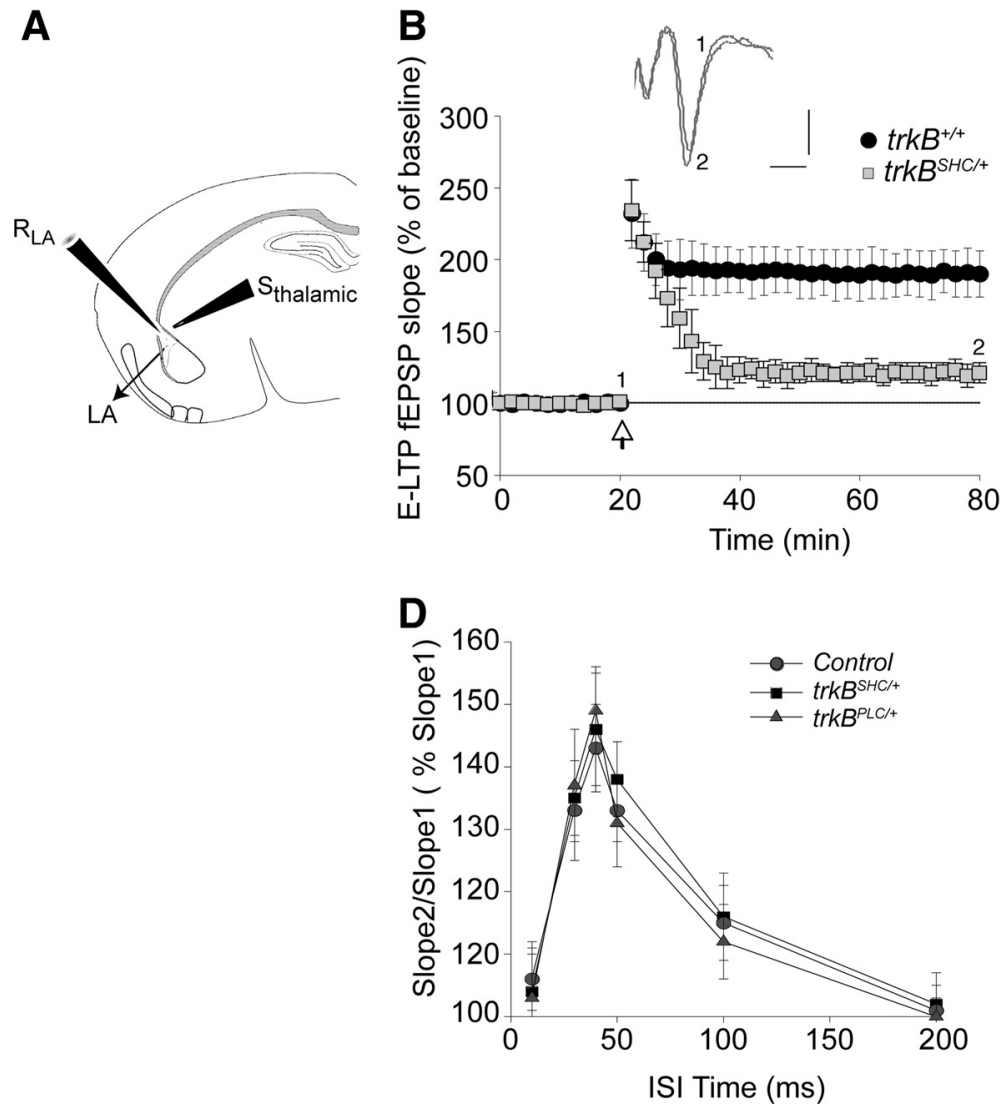

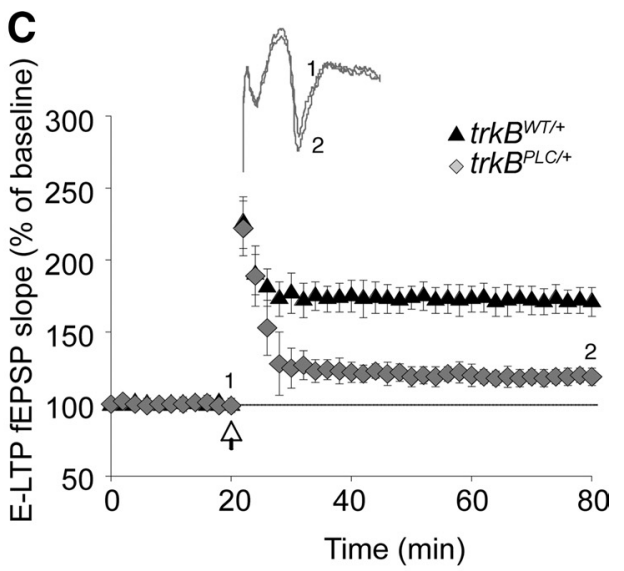

E

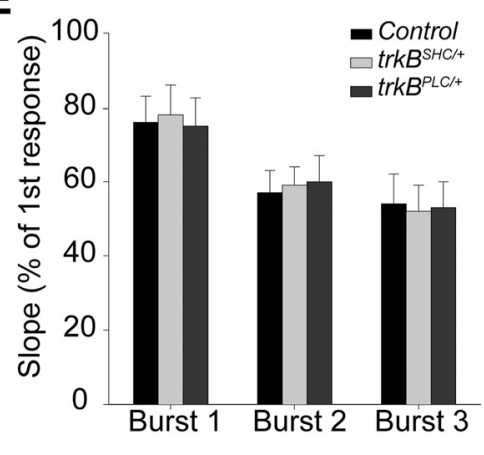

Figure 5. Synaptic plasticity at the thalamic-lateral amygdala synapses is impaired in both $\operatorname{trk} B^{P L C /+}$ and $t r k B^{S H C /+}$ mutants. $A$, Schematic representation of stimulating ( $\left.S\right)$ and recording (R) electrodes. $B, C$, Symbols represent average responses plotted every 2 min. After 20 min of control recordings, an HFS was presented, as marked by the arrow. Data are represented as the mean \pm SEM. $\boldsymbol{B}, \mathrm{E}-\mathrm{LTP}$ was significantly reduced in $\mathrm{trkB} \mathrm{B}^{\mathrm{SHC} /+}$ mutant mice. $p<0.01$ compared with control mice (trkB ${ }^{+/+}$). $\boldsymbol{C}$, E-LTP was also significantly reduced in trkB ${ }^{P L C /+}$ mutants. $p<0.01$ compared with control mice $\left(t r k B^{W T /+}\right)$. Traces show EPSP before (1) and 60 min after (2) LTP protocol was applied. Calibration: $5 \mathrm{~ms}, 0.5 \mathrm{mV}$. The number of slices was four for trkB $B^{+/+}$and trkB $B^{S H C /+}$ mice and five for $t r k B^{W T /+}$ and $t r k B^{P L C /+}$ mice. $D$, PPF was measured to determine whether this aspect of synaptic transmission was normal in trkB $B^{S H C /+}$ and $t r k B^{P L C /+}$ mice compared with controls $\left(t r k B^{+/+}\right.$and $t r k B^{W T /+}$, respectively). The percentages denote the ratio of the second fEPSP slope to the first fEPSP slope. PPF was tested at 10, $30,40,50,100$, and 200 ms ISI. There was no significant difference between genotypes. Error bars correspond to the SEM. $\boldsymbol{E}$, Data corresponding to controls and to $\operatorname{trkB}^{\mathrm{SHC} /+}$ and $t r k B^{P L C /+}$ mutants during high-frequency stimulation. Plotted is the ratio of the fourth to the first response in a burst of four stimuli during theta-burst stimulation. For LTP induction, three theta bursts were applied, and data for all three are shown. Synaptic fatigue can be observed in all genotypes with no statistically significant difference between controls and trkB ${ }^{S H C /+}$ and trkB $B^{P L C /+}$ mice ( $p>0.1 ;$ Student's $t$ test).

between the three genotypes $(p>0.1)$. Similar results were obtained for the homozygous point mutants of both strains $\left(\operatorname{trk} B^{P L C / P L C}, 24.6 \pm 5 \%\right.$; $\left.\operatorname{trk} B^{S H C / S H C}, 23.9 \pm 4 \%\right)$. The NMDA component of the fEPSP was in all cases reduced to zero when the NMDA receptor antagonist AP-5 was added to the bath in the presence of CNQX, indicating that the remaining EPSP component after CNQX application is indeed the NMDA component of the fEPSP. The AMPA/kainate component of the fEPSP from $\operatorname{trkB} B^{P L C /+}$ and $\operatorname{trkB} B^{S H C /+}$ mutants was also comparable with that of control mice. Finally, to test whether LTP blockade was attributable to impaired fiber function or to altered neurotransmitter release probabilities, we analyzed the EPSP slope during thetaburst stimulation. Synaptic fatigue during high-frequency stimulation (HFS) was observed in all genotypes. To quantify these effects we compared the fourth and first responses in a burst of four stimuli and calculated the ratio for burst 1 , burst 2 , and burst 3 (B1, B2, and B3). There were no statistically significant differences between all genotypes analyzed ( $p>0.1$; Student's $t$ test) (Fig. 3D-F), including the homozygous point mutants for both strains ( $\operatorname{trkB}{ }^{P L C / P L C}, \mathrm{~B} 1: 78 \pm 6 \%, \mathrm{~B} 2: 60 \pm 5 \%, \mathrm{~B} 3: 53 \pm 6 \%$; trkB $B^{S H C / S H C}, \mathrm{~B} 1: 76 \pm 6 \%$, B2: $57 \pm 5 \%$, B3: $\left.54 \pm 6 \%\right)$. Collectively, these experiments demonstrate that basal synaptic transmission is normal in all the genotypes analyzed but synaptic strengthening is impaired in $\operatorname{trk} B^{P L C /+}$ mutants.

\section{Long-lasting LTP is strongly impaired at BL synapses in} trkB ${ }^{P L C}$ mutants

As $t r k B^{P L C /+}$ mutants showed impaired long-term contextual and auditory-cued fear memory, and the $\operatorname{trk} B^{S H C /+}$ mutants showed impaired long-term memory (LTM) for cued FC, we also measured L-LTP, which like LTM requires new protein synthesis. Repeated theta bursts or tetanic stimuli were applied to induce L-LTP [three series of 100 pulses $(100 \mathrm{~Hz})$ for a pulse length of $100 \mu \mathrm{s}, 5 \mathrm{~min}$ ISI]. As illustrated in supplemental Figure S6C, available at www.jneurosci.org as supplemental material, slices from control and $t r k B^{S H C /+}$ mice showed L-LTP in $100 \%$ and $90 \%$ of the cases, respectively (5-10 slices from three mice per group), and similar results were observed in the $\operatorname{trkB} B^{S H C / S H C} \mathrm{mu}-$ tants (100\%, 7 slices from three mice). Conversely, the $t r k B^{P L C /+}$ mutants did not show L-LTP $(0 \%$ of cases, zero of five slices from three mice; similar results were obtained in $t r k B^{P L C / P L C}$ mutants). In this analysis, only slices that showed E-LTP were included. The application of a stronger stimulus (normally used to induce L-LTP) partially rescued the E-LTP in the $\operatorname{trk} B^{P L C /+}$ mutants; the magnitude of the potentiation increased from $102 \pm 3$ (Fig. $2 C$ ) to $135 \pm 9(p<0.01)$ (five slices of nine) after LTP induction (Fig. 4C). Nonetheless L-LTP still failed in $t r k B^{P L C /+}$ mutants; the magnitude of the potentiation (expressed as the mean fEPSP slope percentage of the baseline at 175-180 min after TBS) was 
A

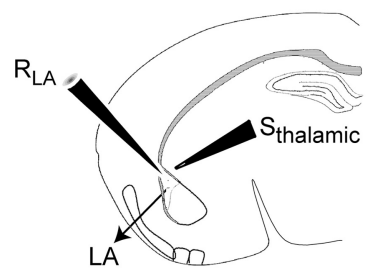

B

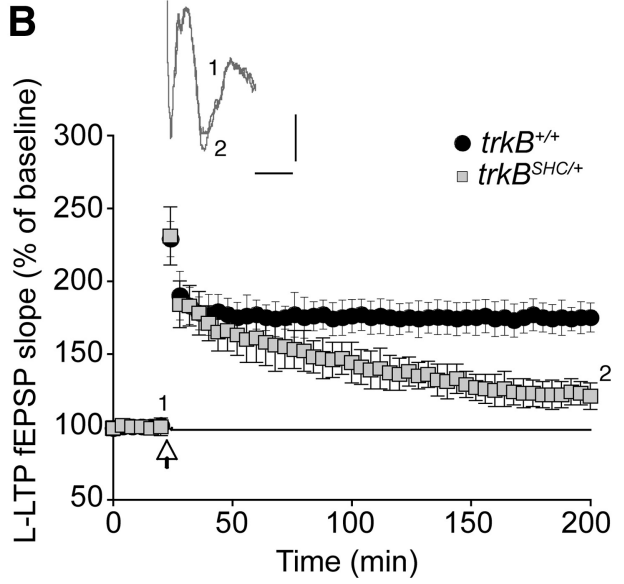

C

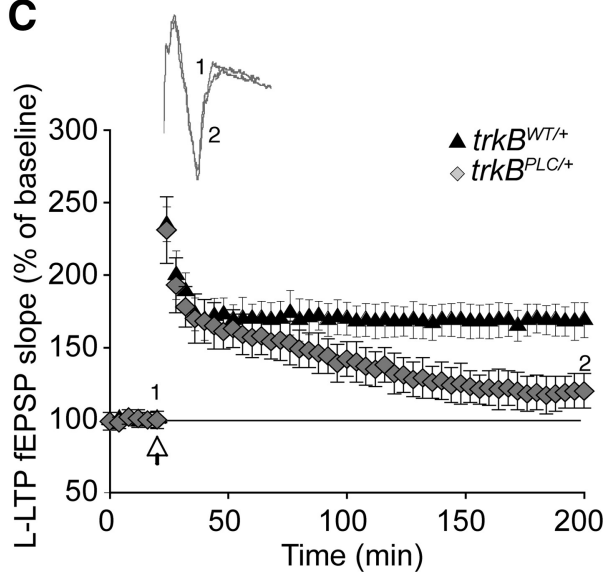

Figure 6. Long-lasting LTP is also reduced in trkB ${ }^{S H C /+}$ and trkB $B^{P L C+}$ mutants at thalamic-lateral amygdala synapses. $A$, Schematic representation of stimulating (S) and recording (R) electrodes. B, C, Slope size of fEPSP recordings before and after the TBS stimulus was plotted. Symbols represent average responses plotted every 4 min. After 20 min of control recordings, HFSs were presented at the time marked by the arrow. Data are represented as the mean \pm SEM. B, L-LTP was significantly reduced in $\operatorname{trk} B^{\text {SHC/+}}$ mutants compared with control mice $\left(\right.$ trkB $\left.{ }^{+/+}\right) ; p<0.01$. C, L-LTP was significantly reduced also in trkB ${ }^{P L C /+}$ mice compared with control mice $\left(t r k B^{W T /+}\right) ; p<0.01$. Traces show EPSP before (1) and 180 min after (2) LTP protocol was applied. Calibration: $5 \mathrm{~ms}, 0.5 \mathrm{mV}$. Four slices were analyzed for trkB ${ }^{+/+}$mice, six for $t r k B^{S H C /+}$ mice, and five for trkB ${ }^{W T /+}$ and trkB ${ }^{P L C /+}$ mice.

$167 \pm 8 \%$ for the $\operatorname{trk} B^{+/+}$control mice, $171 \pm 12 \%$ for the trkB $B^{S H C /+}$ mutants, $161 \pm 9 \%$ for the $\operatorname{trk} B^{W T /+}$ controls, and $105 \pm 6 \%$ for the $\operatorname{trk} B^{P L C /+}$ mutant mice (Fig. $4 B, C$ ). Differences between the controls and the $t r k B^{P L C /+}$ mutant were statistically significant $(p<0.05)$. These results indicate that the signaling activated through the PLC $\gamma$ site of the TrkB receptor is necessary for the acquisition of the pavlovian FC paradigm as well as for LTP generated at synapses in the BL nucleus of the amygdala. In contrast, the $\mathrm{TrkB} / \mathrm{Sh}$ c site-activated signaling is dispensable for plasticity at BL synapses.

\section{E-LTP is impaired at the LA synapses in both $\operatorname{trk} B^{P L C}$ and trkB ${ }^{S H C}$ phosphorylation mutants}

The dorsal subdivision of the LA is the primary target of thalamic inputs (Rodrigues et al., 2004a). Thus, field recordings were obtained in the neurons of the dorsal LA nucleus in brain slices of adult mice by stimulating fibers emerging from the internal capsule in the ventral striatum, which has been shown to carry, in part, efferents from the medial geniculate nucleus to the LA (Weisskopf et al., 1999). This form of LTP is essential for auditory FC in mice (LeDoux, 2000). We used TBS as well as tetanus stimulation. Both protocols evoked LTP: C57BL/6 or $\operatorname{trk} B^{+/+}$ control mice showed LTP in $100 \%$ of the cases ( 16 slices or 4 slices from eight or three mice each group, respectively), $t r k B^{W T /+}$ control mice showed LTP in $80 \%$ of the cases ( 5 slices from three mice), $t r k B^{S H C /+}$ mice showed LTP in $25 \%$ of the cases ( 4 slices from three mice), and $t r k B^{P L C /+}$ mice showed LTP in $40 \%$ of the cases ( 5 slices from three mice) (supplemental Fig. S7A, available at www.jneurosci.org as supplemental material). The magnitude of the potentiation, expressed as the mean percentage of fEPSP slope with respect to baseline (set at $100 \%$ ) was quantified at 55-60 min after stimulation as follows: $\mathrm{rrkB}^{+/+}$control mice, $190 \pm 16 \%$, trkB $^{S H C /+}$ mice, $121 \pm 7 \%$, trkB ${ }^{W T /+}$ controls, $172 \pm$ $10 \%$, and $t r k B^{P L C /+}$ mice, $119 \pm 5 \%$ (Fig. $5 B, C$ ). The differences between controls and $t r k B^{S H C /+}$ mutants, as well as between controls and $\operatorname{rkk}^{P L C /+}$ mice, were significant $(p<0.01)$ (Student's $t$ test, two tailed). Similar results were obtained for the $\operatorname{trk} B^{S H C / S H C}$ and the $\operatorname{trk} B^{P L C / P L C}$ homozygous point mutants (supplemental Fig. S7 $B$, available at www.jneurosci.org as supplemental material). Thus, both $\operatorname{trk} B^{S H C /+}$ and $\operatorname{trk} B^{P L C /+}$ mice showed reduced E-LTP in the auditory input pathways to the LA. Control ex- periments suggested that the reduced E-LTP observed in both trkB $B^{S H C /+}$ and $t r k B^{P L C /+}$ mutants was not caused by impaired synaptic transmission, as it was indistinguishable from that of control mice at LA synapses. PPF was normal in all genotypes analyzed (Fig. 5D). To test whether poor LTP induction at LA synapses in $t r k B^{S H C /+}$ and $t r k B^{P L C /+}$ mice was attributable to impaired fiber function or to altered neurotransmitter release probabilities, we analyzed the EPSP slope during theta-burst stimulation. Synaptic fatigue during high-frequency stimulation was observed in all genotypes. Comparing the fourth and first responses in a burst of four stimuli, and calculating this ratio for the three theta bursts given, revealed no statistically significant differences between all genotypes analyzed ( $p>0.1$; Student's $t$ test) (Fig. 5E). These experiments indicated that basal synaptic transmission is normal in all the genotypes analyzed, but synaptic strengthening is reduced at the LA synapses in $\operatorname{trk} B^{S H C /+}$ and trkB $B^{P L C /+}$ point mutants. Of note is that short-term memory (STM) in $\operatorname{trkB}{ }^{S H C /+}$ mutants is intact $30 \mathrm{~min}$ after training, whereas LTP in amygdala slices is decayed to baseline within 30 min. This suggests that the electrical pattern of stimulation necessary to induce LTP in vitro could be quantitatively different from the natural pattern of activation in the LA of behaving mice during CS-US pairings. In addition, the preparation of the brain slices for the in vitro experiments could disrupt modulatory inputs that are normally present in vivo (Schafe et al., 2001).

\section{$\mathrm{L}-\mathrm{LTP}$ is reduced at the LA synapses in $t r k B^{S H C}$ and $t r k B^{P L C}$ mutants}

We then looked at expression of LTP at the thalamic-LA synapses of both $t r k B^{S H C /+}$ and $t r k B^{P L C /+}$ mutants by using the L-LTP paradigm induced with a stronger stimulus protocol (Fig. $6 B$ ). As illustrated in supplemental Figure S7C, available at www. jneurosci.org as supplemental material, slices from control mice $\left(t r k B^{+/+}\right.$or $t r k B^{W T /+}$ ) showed L-LTP in $100 \%$ of cases (four or five slices, respectively, from three mice), whereas $t r k B^{S H C /+}$ showed L-LTP in $33.3 \%$ of cases (six slices from three mice), and similar results were observed in $t r k B^{S H C / S H C}$ mice (42.8\%) (seven slices from three mice). The $t r k B^{P L C /+}$ mutants showed L-LTP in $40 \%$ of cases (five slices from three mice), and similar results were obtained in $t r k B^{P L C / P L C}$ mutants. All of the slices analyzed showed E-LTP. In particular, with the stronger stimulus protocol the 
A
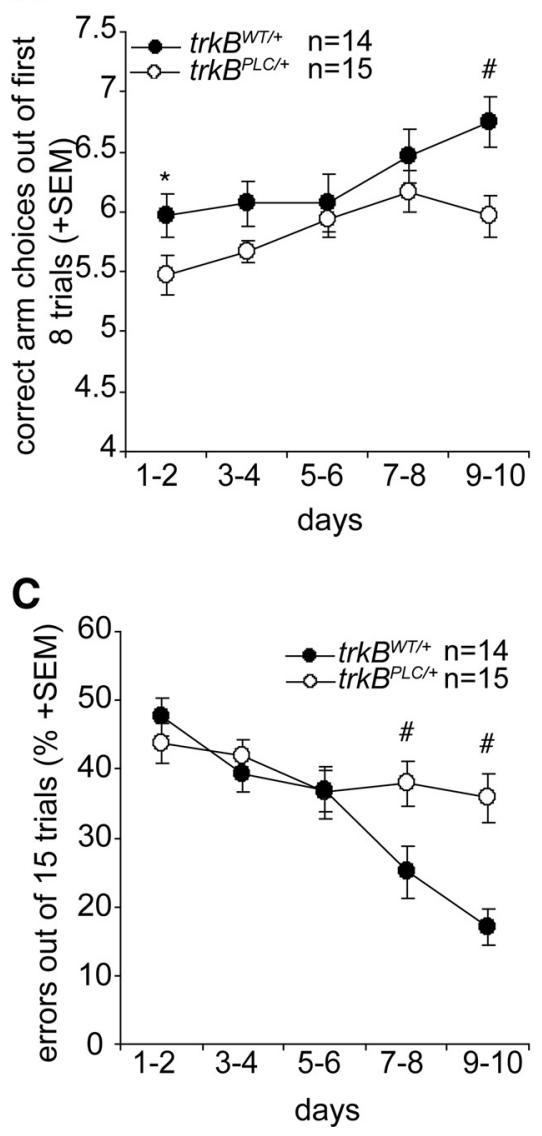

B

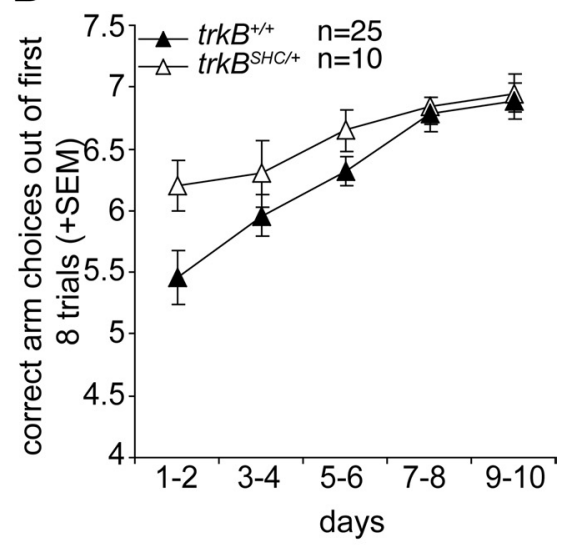

D

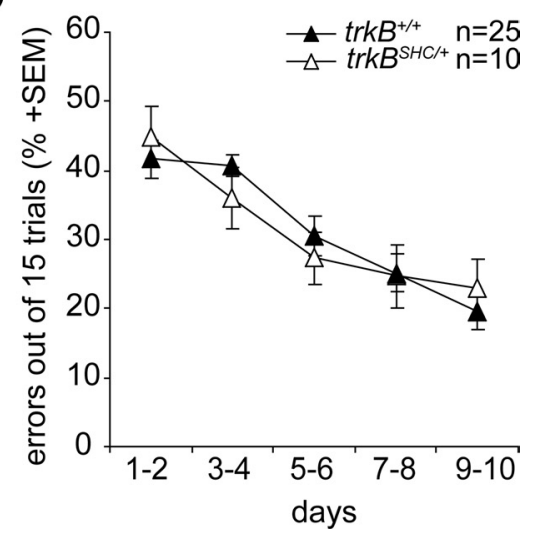

that the hippocampal formation, contrary to what is seen for the $\operatorname{trk} B^{P L C /+}$ mice, is intact in the $\operatorname{trkB} B^{S H C /+}$ mutants, as they showed specific impairment in fear responses to cue stimuli but not to context. Indeed, we have previously shown by in vitro and in vivo electrophysiology that the PLC $\gamma$ docking site, but not the Shc docking site, is necessary to mediate the TrkB-dependent hippocampal late LTP (Minichiello et al., 2002; Gruart et al., 2007). However, we have also shown by in vivo electrophysiology an enhancement of TrkB-dependent hippocampal early LTP evoked in alert behaving $\operatorname{trk} B^{S H C /+}$ point mutant mice (Gruart et al., 2007). The latter results are partially in agreement with results describing an enhancement of hippocampal early LTP by in vitro electrophysiology in ShcC mutant mice; ShcC is a member of the Shc family of adapter molecules, predominantly expressed in the nervous system (Miyamoto et al., 2005). To further test the functioning of the hippocampus in relation to behavior, we subjected the $t r k B^{P L C /+}$ and the trkB ${ }^{S H C /+}$ mutant and control groups to the eight-arm radial maze task, which depends on an intact hippocampus (Olton et al., 1978; Rossi-Arnaud and Ammassari-Teule, 1998; Minichiello et al., 1999) and allows for the assessment of spatial learning and memory in rodents. In this paradigm, rodents are trained to visit a number of arms to receive a food reward. To properly perform the task, animals must use spatial information to remember which $\operatorname{arm}(\mathrm{s})$ of the maze was already visited. Our analysis of

Figure 7. Spatial learning is severely impaired in $t r k B^{P L C /+}$ but not in $t r k B^{S H C /+}$ point mutants. $A-D$, Mice were trainedf consecutive days in a fully baited eight-arm radial maze. Learning performance is expressed as the mean number of correct arm choices in the first 8 trials, which is a measure of spatial working memory $(\boldsymbol{A}, \boldsymbol{B})$, and the percentage of errors until eight correct choices were observed or after the maximal permitted number of trials (15), which reflect long-term spatial memory $(\boldsymbol{C}, \boldsymbol{D}) . \boldsymbol{A}, \boldsymbol{C}$, The performance of the $t r k B^{P L C /+}$ mice was significantly impaired compared with the trkB ${ }^{W T /+}$ control mice in all measures considered. $\boldsymbol{B}, \boldsymbol{D}$, In contrast, the performance of the $\operatorname{trk} B^{\mathrm{SHC} /+}$ mice was very similar to that of $\operatorname{trk} B^{+/+}$control mice in both the correct arm choices in the first eight trials and the percentage of errors. ${ }^{*} p<0.05 ;{ }^{\#} p<0.005$.

EPSP slope size increased from $121 \pm 7$ to $152 \pm 14(p<0.01)$ (six slices of nine) in $t r k B^{S H C /+}$ mutants and from $119 \pm 5$ to $148 \pm 12(p<0.01)$ (five slices of eight) in $\operatorname{trk} B^{\text {PLC/+ }}$ mutants. However, slices from both the $\operatorname{trk} B^{S H C /+}$ and the $\operatorname{trk} B^{P L C /+}$ mutants presented reduced L-LTP; the magnitude of the potentiation (expressed as the mean fEPSP slope percentage of the baseline at 175-180 min after TBS) was as follows: for the $t r k B^{+/+}$ control mice, $175 \pm 10 \%$; for the trkB ${ }^{S H C /+}$ mice, $122 \pm 6 \%$; for the $\operatorname{trk} B^{W T /+}$ mice, $169 \pm 12 \%$; and for the $\operatorname{trk} B^{P L C /+}$ mice, $119 \pm$ $10 \%$ (Fig. $6 B, C$ ). The differences between controls and trkB $B^{\text {SHC/+ }}$ mutants as well as controls and $\operatorname{trkB} B^{P L C /+}$ mice were significant $(p<0.01)$ (Student's $t$ test, two tailed). Similar results were obtained for the $\operatorname{trkB} B^{S H C / S H C}$ and the $\operatorname{trk} B^{P L C / P L C}$ homozygous point mutants (supplemental Fig. S7D, available at www. jneurosci.org as supplemental material).

\section{Point mutation at the Shc site in TrkB impairs specific amygdala function but not hippocampal function}

It has been suggested that the amygdala is essential for the conditioning of fear responses to both a cue and a context, whereas the hippocampus is involved in contextual but not auditory-cued fear conditioning (Phillips and LeDoux, 1992). The differential involvement of the Shc and the PLC $\gamma$ phosphorylation sites of TrkB in fear learning and amygdalar synaptic plasticity indicates the number of correct arm choices (during the first eight choices) showed that the $\operatorname{trk} B^{P L C /+}$ mutants (compared with the $\operatorname{trk} B^{W T /+}$ control mice) and the $t r k B^{S H C /+}$ mutants (compared with the $\operatorname{trkB} B^{+/+}$control mice) learned the radial maze $\left(F_{(9.243)}=7.61\right.$; $p<0.0001 ; F_{(9.297)}=9.29 ; p<0.0001$, respectively) (Fig. $7 A, B$ ). However, the $\operatorname{trk} B^{P L C /+}$ mutants learned significantly less than the $\operatorname{trk} B^{W T /+}$ controls $\left(F_{(1.27)}=5.65 ; p<0.05\right)($ Fig. $7 A)$, whereas the $\operatorname{trk} B^{S H C /+}$ mice performed similarly to controls $\left(F_{(1.33)}=\right.$ $0.009 ; p>0.05$ ) (Fig. 7B). The analysis of the error scores of 15 trials (maximum permitted number of trials) revealed significantly higher error scores for the $\operatorname{trk} B^{P L C /+}$ mutants compared with controls $\left(\operatorname{trk} B^{W T /+}\right)\left(F_{(1.27)}=6.53 ; p<0.05\right)($ Fig. $7 C)$. Interestingly, as previously observed in adult mice lacking $T r k B$ in all principal neurons (the trkBcre mice) (Minichiello et al., 1999), the percentage of errors committed by the $t r k B^{P L C /+}$ mice was significantly higher than that of $\operatorname{trk} B^{W T /+}$ mice $\left({ }^{\#} p<0.005\right)$ during the last days of the test, whereas the $\operatorname{trk} B^{S H C /+}$ mice and trkB $B^{+/+}$mice committed very few errors during the same period of the session and were statistically indistinguishable (Fig. 7C,D). When the occurrence of the first error was considered, $\operatorname{trk} B^{\text {SHC/+ }}$ mice performed significantly better than $\operatorname{trk} B^{+/+}$mice during the first $6 \mathrm{~d}$ of training $\left({ }^{*} p<0.05\right)$. However, the performance of trkB $B^{S H C /+}$ and $\operatorname{trk} B^{+/+}$animals became statistically indistinguishable during the last $2 \mathrm{~d}$ of training (supplemental Fig. 




D

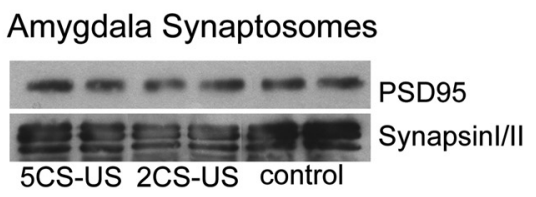

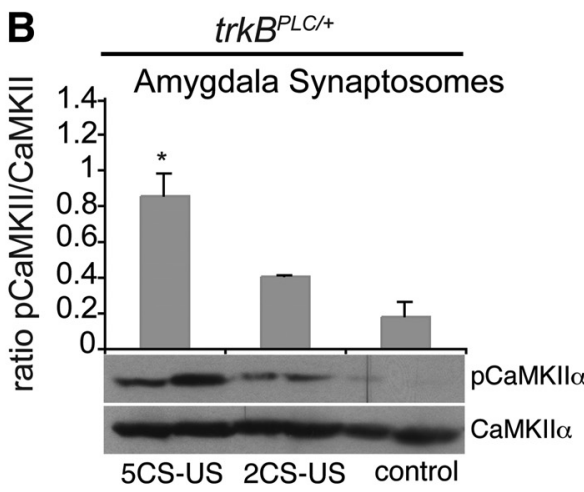

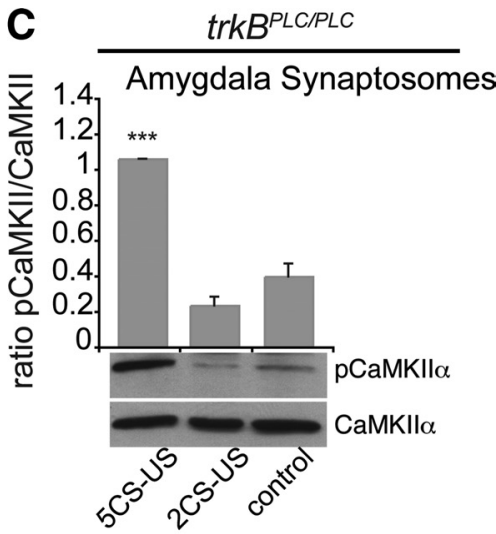

E

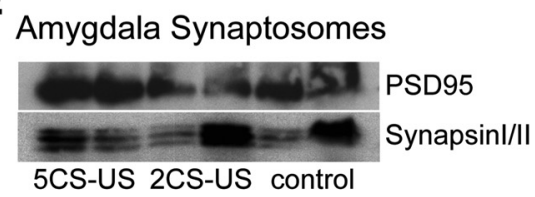

$\mathbf{F}$

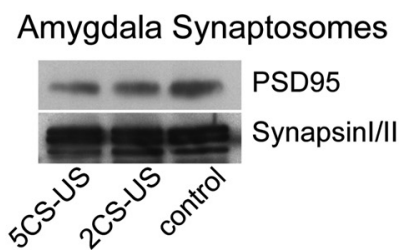

Figure 8. Weak pCaMKII at amygdala synapses in $\operatorname{trkB}^{P L C}$ point mutants correlates with impaired fear acquisition. $\boldsymbol{A}-\boldsymbol{C}$, Immunoblots showing pCaMKII (Thr ${ }^{286}$ ) levels in synaptosomal preparations from amygdala tissues of $t r k B^{+/+}$untrained (control, $n=4$ ) versus trained ( 2 CS-US, $n=5 ;$ or 5 CS-US, $n=5$ ), trkB $B^{P L C /+}$ (control, $n=3 ; 2$ CS-US, $n=3 ;$ or 5 CS-US, $n=3$ ) and $\operatorname{trkB}^{P L C / P L C}$ (control, $n=3 ; 2$ CS-US, $n=3$; or 5 CS-US, $n=3$ ) mice. Blots were reprobed with CaMKII $\alpha$ Abs to visualize CaMKIl $\alpha$ levels. Top, Quantification of pCaMKII levels $A$, ${ }^{* *}$, ANOVA, five CS-US versus control, $p=0.0059 ;{ }^{*}$, two CS-US versus control, $p=0.047$. $\boldsymbol{B},{ }^{*}$, ANOVA, five CS-US versus control, $p=0.01$; five CS-US versus two CS-US, $p=0.03$. C, ${ }^{* * *}$, ANOVA, five CS-US versus control, $p=0.0007$; five CS-US versus two CS-US, $p=0.0002$. D $-\boldsymbol{F}$, Immunoblots of PSD95 and synapsin I/II confirmed that the synaptosomal preparation from amygdala tissues contained both post- and presynaptic fractions, respectively.

S8 $A, B$, available at www.jneurosci.org as supplemental material). Together, these results show a clear impairment in both short- and long-term spatial memory in mice carrying a point mutation at the PLC $\gamma$ site of the TrkB receptor but not at the Shc site.

\section{CaMKII phosphorylation is weak in amygdala synapses of} trkB ${ }^{P L C}$ point mutants

It has been suggested that the phosphorylation at $\mathrm{Thr}^{286}$ of CaMKII $\alpha$ is critically involved in synaptic plasticity and the acquisition and/or initial formation of short-term memory during fear conditioning in the LA. CaMKII $\alpha$ is found to be distributed throughout the LA and to be postsynaptic to thalamic inputs. In addition, inhibition of CaMKII in the amygdala impairs the acquisition of auditory and contextual fear conditioning (Rodrigues et al., 2004b). BDNF has been shown to induce the phosphorylation of this kinase in neurons (Finkbeiner et al., 1997), and we have previously shown that CaMKII phosphorylation is impaired in $t r k B^{P L C / P L C}$ but not $t r k B^{S H C / S H C}$ mutant synaptosomal preparations isolated from adult mouse cerebral cortices and stimulated with BDNF (Minichiello et al., 2002). Here, we found that point mutation at the PLC $\gamma$ site of TrkB results in impaired fear acquisition and impaired amygdalar synaptic plasticity at the LA and the BL synapses. To further examine the mechanism by which the PLC $\gamma$ site of TrkB regulates conditioned fear responses and LTP at amygdalar synapses, we measured the activation $\left(\mathrm{p}-\mathrm{Thr}^{286}\right)$ of CaMKII in untrained (control) versus fear-conditioned mice. Since it has been reported that fear conditioning increases CaMKII phosphorylation at the lateral amygdala spines (Rodrigues et al., 2004b), and we found that impairments in the acquisition of conditioned fear responses by $\operatorname{trk} B^{P L C /+}$ mutant mice are revealed with a milder (two CS-US pairings), but not an intense (five CS-US pairings), conditioning trial, we asked whether the degree of CaMKII phos- phorylation at amygdalar synapses correlated with the acquisition of conditioned fear in the $\operatorname{trk} B^{P L C /+}$ mutants. No differences in pCaMKII levels were found in synaptosomes isolated from trkB $B^{P L C /+}$ mice that were either unconditioned or trained using two CS-US pairings (ANOVA, two CS-US versus control, $p=$ 0.16 ); however, a significant increase in pCaMKII levels was seen in amygdalar synaptosomes from $\operatorname{trk} B^{P L C /+}$ mice trained with five CS-US pairings (ANOVA; five CS-US versus control, $p=$ 0.01; five CS-US versus two CS-US, $p=0.03$ ) (Fig. $8 B$ ). The pCaMKII levels in synaptosomes from $\operatorname{trk} B^{P L C / P L C}$ mice either untrained (control) or conditioned with two CS-US or five CS-US pairings were similarly affected (ANOVA; two CS-US versus control, $p=0.09$; five CS-US versus control, $p=0.0007$; five CS-US versus two CS-US, $p=0.0002$ ) (Fig. $8 C$ ). Conversely, amygdalar synaptosomes isolated from $\operatorname{trk} B^{+/+}$mice trained with either two CS-US or five CS-US pairings possessed similar levels of pCaMKII that were significantly greater than the level seen in untrained $t r k B^{+/+}$mice (ANOVA; two CS-US versus control, $p=0.047$; five CS-US versus control, $p=0.0059$; two CS-US versus five CS-US, $p=0.3$ ) (Fig. $8 A$ ). Collectively, these results suggest that impaired fear acquisition and amygdalar synaptic plasticity downstream of the TrkB/PLC $\gamma$ site correlate with weak pCaMKII at the amygdalar synapses.

AKT but not MAPK phosphorylation is affected in amygdala synapses of $t r k B^{S H C}$ point mutants

Previously, we showed normal MAPK activation and nuclear translocation after BDNF stimulation in dissociated cortical neurons from $t r k B^{P L C / P L C}$ mice (Minichiello et al., 2002). In contrast, in cortical neurons from $\operatorname{trk} B^{S H C / S H C}$ mutants the activation of MAPK by BDNF is transient and reduced in amplitude (Minichiello et al., 1998). Thus, we analyzed MAPK phosphorylation in response to BDNF in cultured cortical neurons from trkB $B^{S H C /+}$ mutants and found similar activation kinetics compared 

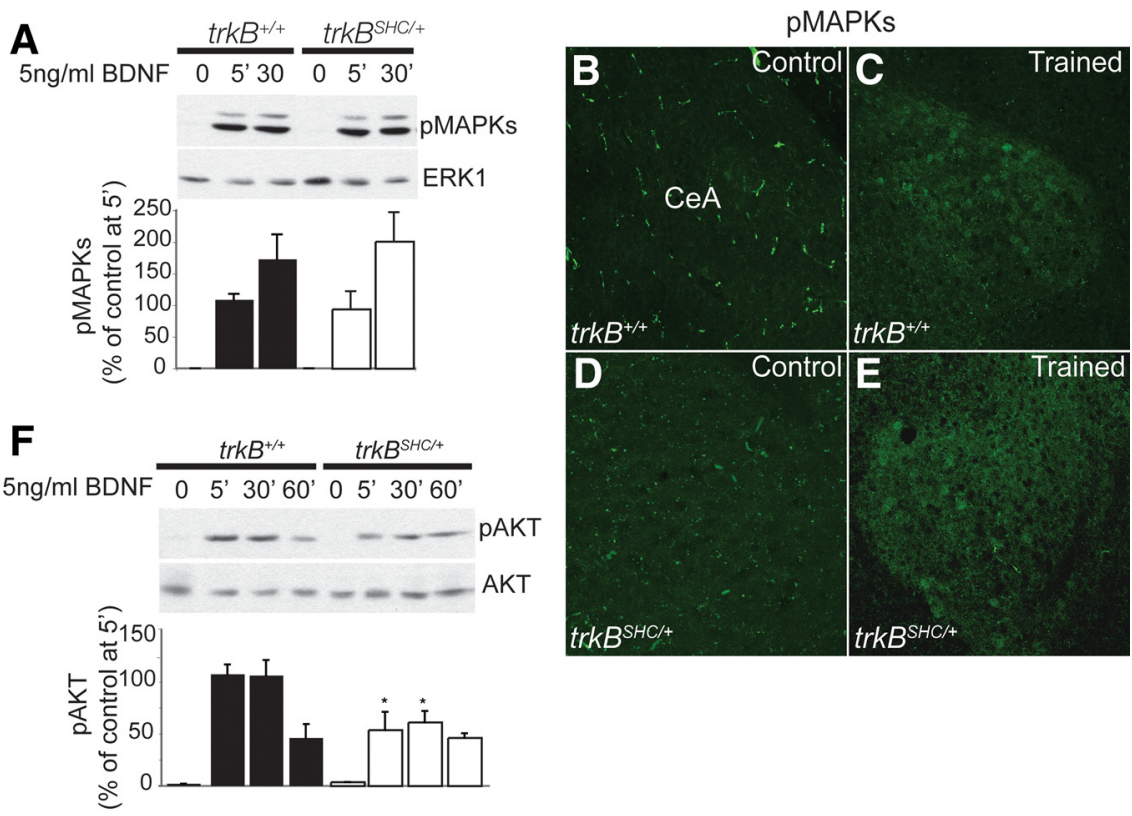

G
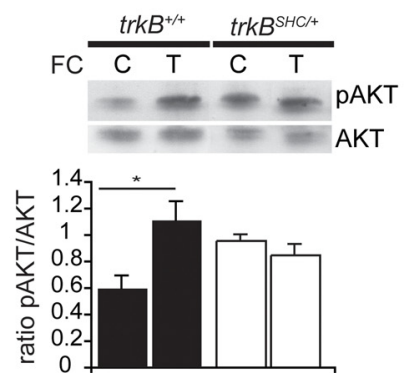

Figure 9. Decreased pAKT but not pMAPKs in trkB ${ }^{S H C /+}$ point mutants. A, Top, Immunoblot showing the time course of MAPK phosphorylation after BDNF stimulation of control and trkB $B^{\mathrm{SHC} /+}$ mutant cortical primary neurons using Abs against the phosphorylated forms of ERK1/2, p42/44 (pMAPKs). To control for protein loading, the blots were reprobed with anti-ERK1 Abs. Bottom, Quantification of pMAPK levels. Densitometric analysis was performed on two different blots for each antibody ( $n=3$ cortices per time point). $\boldsymbol{B}-\boldsymbol{E}$, Immunofluorescence analysis of amygdala tissues from fear-conditioned $(n=3)$ versus untrained $(n=2)$ $\operatorname{trkB}^{+/+}$and trkB $B^{\text {SHC/+}}$ mice by use of pMAPKs Abs. $\boldsymbol{F}$, Top, Immunoblot showing the time course of AKT phosphorylation after BDNF stimulation of control and trKB ${ }^{\mathrm{SHC} /+}$ mutant cortical primary neurons by using pAKT antibodies. To control for protein loading, blots were reprobed with anti-AKT Abs. Bottom, Quantification of pAKT levels. ${ }^{*}$, pAKT in trkB ${ }^{S H C /+}$ versus trkB ${ }^{+/+}, p=$ 0.02 , ANOVA. Densitometric analysis was performed on two different blots for each antibody ( $n=3$ cortices per time point). $\mathbf{G}$, Top, Immunoblot analysis of pAKT in amygdala lysates from trkB ${ }^{+/+}$untrained (control) $(n=2)$ versus trained (fear-conditioned) $(n=3)$ amygdala lysate and from $\mathrm{trKB}^{\mathrm{SHCl+}}$ mice (control) $(n=2)$ versus trained (fear-conditioned) $(n=3)$ amygdala lysate. To control for protein loading, blots were reprobed with anti-AKT Abs. Bottom, Quantification of pAKT levels. ${ }^{*} p=0.01$. C, Control (untrained); $T$, trained.

with BDNF-treated cultures from $t r k B^{+/+}$control mice $(5$ min trkB $B^{S H C /+}$ versus 5 min $t r k B^{+/+}, p=0.7 ; 30$ min $t r k B^{S H C /+}$ versus $30 \mathrm{~min} t r k B^{+/+}, p=0.5$ ) (Fig. $9 A$ ). As expected, $\operatorname{trk} B^{P L C /+}$ mutant cortical neurons showed normal activation of MAPKs in response to $\mathrm{BDNF}$ (data not shown). Moreover, to elucidate the contribution of MAPK to TrkB/Shc site-dependent amygdala function, MAPK phosphorylation was examined in the amygdala of untrained or fear-conditioned $t r k B^{S H C /+}$ mice. Immunostaining of amygdalae for pMAPKs produced similar results for $t r k B^{S H C /+}$ and $t r k B^{+/+}$mice (Fig. $9 B-E$ ). We have previously shown that the phosphorylation of AKT in response to BDNF is not affected in cortical neurons of $t r k B^{P L C / P L C}$ mutants but is significantly reduced in $t r k B^{S H C / S H C}$ mutants (Postigo et al., 2002; Medina et al., 2004). This prompted us to analyze the kinetics of PI3K/AKT activation in cortical neurons from $t r k B^{S H C /+} \mathrm{mu}-$ tants. Remarkably, AKT phosphorylation after BDNF treatment was significantly reduced compared with controls ( $5 \mathrm{~min}$
trkB $B^{S H C /+}$ versus 5 min $t r k B^{+/+}, p=0.02$; $30 \mathrm{~min} t r k B^{S H C /+}$ versus 30 min $\operatorname{trk} B^{+/+}$, $p=0.02$ ) (Fig. 9F). Similar results were observed in amygdala tissue lysate from conditioned versus naive animals. Whereas fear conditioning increased pAKT levels in $t r k B^{+/+}$amygdalar tissue $(p=0.01)$, no significant difference was observed in the amygdala tissue of conditioned versus untrained $t r k B^{S H C /+}$ mice $(p=0.4)$ (Fig. 9G). These results suggested that the consolidation of cued fear conditioning and the maintenance of TrkB-dependent LTP in the LA mainly require activation of the PI3K/AKT pathway through the Shc site.

\section{Discussion}

Ntrk2/TrkB receptors are essential for synaptic plasticity and learning in different paradigms, including pavlovian fear conditioning. However, the molecular pathways required for fear learning and amygdalar synaptic plasticity downstream of the TrkB receptor have not yet been identified. The brain structure central to the fear memory circuits is the amygdala, in particular substructures that form the BLA complex (LA, BL, BM) and the output nucleus CeA (LeDoux, 2000; Maren, 2001). It is clear that the LA plays an essential role in the acquisition and maintenance of fear memories. However, latest evidence suggests that LA, $\mathrm{BL}$, and CeA perform certain associative functions in parallel (Everitt et al., 2003; Paré et al., 2004). It was established that both FC-induced neuronal plasticity and LTP at amygdala synapses share common mechanisms of induction and expression (McKernan and ShinnickGallagher, 1997; Rogan et al., 1997). Thus, to determine whether the molecular mechanisms for pavlovian FC downstream of the TrkB receptor are also required for the induction and expression of long-term synaptic plasticity, such as LTP, we tested highly defined genetic mouse models that carry a point mutation at specific phosphorylation docking sites of the TrkB receptor $\left(\operatorname{trk} B^{S H C}, \operatorname{trk} B^{P L C}\right)$ in a pavlovian FC paradigm (by using heterozygous point mutants, $\operatorname{trk} B^{S H C /+}$, and $\operatorname{trkB} B^{P L C /+}$ ) as well as acquired field recordings from neurons of different amygdala nuclei, including the BL nucleus, by stimulating the LA nucleus, and the LA nucleus by stimulating fibers originating in the auditory thalamus, in brain slices of adult heterozygous $\left(\operatorname{trkB} B^{S H C /+}\right.$ and $\left.\operatorname{trk} B^{P L C /+}\right)$ and homozygous ( $\operatorname{trk} B^{S H C / S H C}$ and trkB ${ }^{P L C / P L C}$ ) point mutant mice and control animals. Remarkably, the results obtained indicate a differential regulation of fear learning and amygdalar synaptic plasticity by the two phosphorylation sites of TrkB receptor. In particular, a point mutation in the TrkB/PLC $\gamma$ site impairs E- and L-LTP in the amygdalar circuits analyzed and also impairs the acquisition of conditioned fear to both context and an auditory cue. It was previously sug- 
gested that the amygdala and the hippocampus differentially contribute to cue and contextual FC. Lesion experiments in rats revealed that whereas the amygdala is involved in the conditioning of fear-related responses to a context and cue, the hippocampus instead modulates conditioning to context but not to a cue (Phillips and LeDoux, 1992). We previously showed that the PLC $\gamma$ docking site, but not the Shc site, of TrkB is necessary for hippocampal synaptic plasticity, as well as for the acquisition of associative learning (classical conditioning of eyelid responses), in vivo LTP at CA3-CA1 hippocampal synapses (Minichiello et al., 2002; Gruart et al., 2007), and spatial learning (this study). Thus, impaired hippocampal plasticity in $\operatorname{trk} B^{P L C}$ mutants likely contributes to the impaired fear conditioning to context. In contrast, the $\operatorname{trk} B^{S H C}$ mutants show normal acquisition of contextual and cued FC but impaired consolidation of the conditioned fear response to an auditory cue, as well as a specific impairment in amygdalar synaptic plasticity at the thalamic-LA synapses (observed in both the $\operatorname{trkB} B^{S H C /+}$ and the $\operatorname{trkB} B^{S H C / S H C}$ mutants). We also obtained recordings within the LA (the ventral LA) by stimulation of the dorsal lateral nucleus and found impaired plasticity in the $\operatorname{trk} B^{S H C}$ mutants (data not shown), suggesting a specific impairment in plasticity in the LA of the $\operatorname{trkB}{ }^{S H C}$ mutants. This is supported by the fact that hippocampal functions are mainly spared in these mutants. Of note is that we have reported by in vivo electrophysiology an enhancement of TrkB-dependent hippocampal early LTP evoked in alert behaving $t r k B^{S H C /+}$ mice (Gruart et al., 2007). Consistent with these results, we now also show a better performance of the $\operatorname{trk} B^{S H C}$ mutants in a specific phase of a spatial learning task (namely, the radial maze). Although these results are similar to some of the results reported for the ShcC mutant mice, the mechanisms by which ShcC regulates hippocampal synaptic plasticity seem to be independent of the TrkB/Shc site and apparently via modulation of the NMDA receptor function (Miyamoto et al., 2005). In addition, transgenic mice overexpressing the full-length TrkB receptor show selective activation of the PLC $\gamma$ site as well as increased spatial learning and improved contextual fear conditioning, whereas signaling via the Shc site remains unaltered (Koponen et al., 2004).

Regarding the biochemical mechanisms underlying pavlovian FC, Rodrigues et al. (2004b) suggested that the phosphorylation of $\mathrm{Thr}^{286}$ of CaMKII $\alpha$ is critically involved in synaptic plasticity and the acquisition and/or initial formation of STM during fear conditioning in the LA. Here, we show that a point mutation at the PLC $\gamma$ site of TrkB $\left(t r k B^{P L C /+}\right)$ results in impaired fear acquisition and impaired amygdalar synaptic plasticity at the LA and the BL synapses, likely attributable to the reduced phosphorylation of CaMKII at $\mathrm{Thr}^{286}$, as seen in amygdalar synapses of FC trkB $B^{P L C}$ mice (both trkB $B^{P L C /+}$ and $t r k B^{P L C / P L C}$ mutants) trained with two CS-US pairings, indicating that TrkB receptors through the Y816 typically modulate CaMKII phosphorylation and acquisition of FC, as well as amygdalar LTP. However, an intense training protocol (five CS-US pairings) induces normal CaMKII phosphorylation in $t r k B^{P L C}$ amygdala synapses (observed in both the $\operatorname{trk} B^{P L C /+}$ and $\operatorname{trk} B^{P L C / P L C}$ mutants). These results were consistent with the fact that training trials using five CS-US pairings rescued the memory acquisition deficit in the $\operatorname{trk} B^{P L C /+}$ mice and that application of a stronger stimulus partially rescued the E-LTP in these mutants. Under conditions of stronger stimulation, classical pathways still activated downstream of the mutant TrkB receptor may compensate for the signaling lost from the PLC $\gamma$ site. Alternatively, recent studies have shown that neurotrophin activation of TrkB can rapidly mediate the gating of so- dium channels, resulting in an increase in intracellular calcium concentration and cellular responses independent of PLC $\gamma$ recruitment to TrkB (Blum and Konnerth, 2005). It is also possible that the effects observed in the $\operatorname{trk} B^{P L C /+}$ mutants under more intense inputs involve the activation of undefined signaling mechanisms directly or indirectly implicated in fear conditioning. The normal phosphorylation of CaMKII seen in the amygdalae of $t r k B^{S H C /+}$ point mutants (data not shown) correlates with their normal acquisition of fear conditioning. Moreover, mice heterozygous for a point mutation at Y515 or Y816 of TrkB possess normal brain levels of BDNF (supplemental Fig. S8, available at www.jneurosci.org as supplemental material), supporting the conclusion that the fear conditioning and the synaptic activity in amygdalar nuclei of these mutants are not affected by changes in the levels of this TrkB ligand.

Gean and colleagues have reported that the PI3K/AKT pathway contributes to amygdalar LTP and the consolidation of amygdala-dependent cued fear conditioning in rats (Lin et al., 2001). Pharmacological studies by the same laboratory revealed that $\mathrm{BDNF}$ is required for the acquisition of fear learning via recruitment of the Shc adapter protein to TrkB and the activation of MAPK and PI3K (Ou and Gean, 2006). As discussed above, by using very precise mouse genetic models we have determined in this study that it is primarily the PLC $\gamma$ site of TrkB that mediates the TrkB-dependent acquisition of FC and amygdalar synaptic plasticity at the LA and the BL synapses through modulation of CaMKII at synapses, whereas the Shc site contributes mainly to consolidation of amygdala-dependent cued fear conditioning and LTP at the LA synapses predominantly through AKT activation.

A concern could be raised that the mice used in this study possess the mutated form of the receptor in all TrkB-expressing cells and this precludes conclusions regarding the role of TrkB in a specific brain region such as the amygdala. However, we have extensively analyzed the PNS and CNS development of the heterozygous point mutants of both strains [shown in previous work (Minichiello et al., 1998, 2002; Medina et al., 2004; Gruart et al., 2007)] (supplemental Figs. S1, S2, available at www.jneurosci.org as supplemental material) and have not identified any relevant abnormalities. This, combined with the fact that the animals display normal basic behavior (supplemental Fig. S3, available at www.jneurosci.org as supplemental material), suggests that the phenotypes observed in fear conditioning are not caused by developmental defects in the amygdala. Experiments based on the intra-amygdala infusion of a lentiviral vector expressing a dominant-negative TrkB isoform (TrkB.T1) in adult rats have also established that the TrkB neurotrophin receptor plays an essential role in the acquisition of pavlovian fear conditioning triggered in the amygdala nuclei (Rattiner et al., 2004). Moreover, we find that basal synaptic activities are similar between the different genotypes analyzed (Fig. 3). Animals possessing developmental defects would show changes especially in basal synaptic transmission. The electrophysiological recordings produced identical results for heterozygous and homozygous point mutants (supplemental Figs. S7-10, available at www.jneurosci. org as supplemental material), suggesting that one copy of a wildtype TrkB allele is sufficient to prevent the developmental PNS phenotypes observed in the homozygous point mutants but is not sufficient to support TrkB-dependent learning in the adult brain (Minichiello et al., 1999, 2002). Similar results were obtained by biochemical analysis of synaptosomal preparations from amygdala tissues of untrained versus trained $\operatorname{trk} B^{P L C /+}$ and $\operatorname{trk} B^{P L C / P L C}$ point mutants (Fig. 8). Together, these findings uphold the no- 
tion that the genetic tools of the present study are valid and support our main conclusions. However, future work focused on a cell-type-specific ablation of TrkB will be necessary to understand the contribution of TrkB to fear learning and amygdalar LTP in the different neuronal populations.

\section{References}

Blum R, Konnerth A (2005) Neurotrophin-mediated rapid signaling in the central nervous system: mechanisms and functions. Physiology 20:70-78.

Campeau S, Davis M (1995) Involvement of subcortical and cortical afferents to the lateral nucleus of the amygdala in fear conditioning measured with fear-potentiated startle in rats trained concurrently with auditory and visual conditioned stimuli. J Neurosci 15:2312-2327.

Davis M (1997) Neurobiology of fear responses: the role of the amygdala. J Neuropsychiatry Clin Neurosci 9:382-402.

Everitt BJ, Cardinal RN, Parkinson JA, Robbins TW (2003) Appetitive behavior: impact of amygdala-dependent mechanisms of emotional learning. Ann N Y Acad Sci 985:233-250.

Fendt M, Fanselow MS (1999) The neuroanatomical and neurochemical basis of conditioned fear. Neurosci Biobehav Rev 23:743-760.

Finkbeiner S, Tavazoie SF, Maloratsky A, Jacobs KM, Harris KM, Greenberg ME (1997) CREB: a major mediator of neuronal neurotrophin responses. Neuron 19:1031-1047.

Gale GD, Anagnostaras SG, Godsil BP, Mitchell S, Nozawa T, Sage JR, Wiltgen B, Fanselow MS (2004) Role of the basolateral amygdala in the storage of fear memories across the adult lifetime of rats. J Neurosci 24:3810-3815.

Gruart A, Sciarretta C, Valenzuela-Harrington M, Delgado-García JM, Minichiello L (2007) Mutation at the TrkB PLC\{gamma\}-docking site affects hippocampal LTP and associative learning in conscious mice. Learn Mem 14:54-62.

Kim JJ, Fanselow MS (1992) Modality-specific retrograde amnesia of fear. Science 256:675-677.

Koo JW, Han JS, Kim JJ (2004) Selective neurotoxic lesions of basolateral and central nuclei of the amygdale produce differential effects on fear conditioning. J Neurosci 24:7654-7662.

Koponen E, Võikar V, Riekki R, Saarelainen T, Rauramaa T, Rauvala H, Taira T, Castrén E (2004) Transgenic mice overexpressing the full-length neurotrophin receptor trkB exhibit increased activation of the trkBPLCgamma pathway, reduced anxiety, and facilitated learning. Mol Cell Neurosci 26:166-181.

Lavond DG, Kim JJ, Thompson RF (1993) Mammalian brain substrates of aversive classical conditioning. Annu Rev Psychol 44:317-342.

LeDoux JE (1996) The emotional brain: the mysterious underpinnings of emotional life. New York: Simon and Schuster.

LeDoux JE (2000) Emotion circuits in the brain. Annu Rev Neurosci 23:155-184.

LeDoux JE, Cicchetti P, Xagoraris A, Romanski LM (1990) The lateral amygdaloid nucleus: sensory interface of the amygdala in fear conditioning. J Neurosci 10:1062-1069.

Lin CH, Yeh SH, Lin CH, Lu KT, Leu TH, Chang WC, Gean PW (2001) A role for the PI-3 kinase signaling pathway in fear conditioning and synaptic plasticity in the amygdala. Neuron 31:841-851.

Maren S (2001) Neurobiology of pavlovian fear conditioning. Annu Rev Neurosci 24:897-931.

Maren S, Aharonov G, Fanselow MS (1997) Neurotoxic lesions of the dorsal hippocampus and pavlovian fear conditioning in rats. Behav Brain Res 88:261-274.

McKernan MG, Shinnick-Gallagher P (1997) Fear conditioning induces a lasting potentiation of synaptic currents in vitro. Nature 390:607-611.

Medina DL, Sciarretta C, Calella AM, Von Bohlen Und Halbach O, Unsicker K, Minichiello L (2004) TrkB regulates neocortex formation through the Shc/PLCgamma-mediated control of neuronal migration. EMBO J 23:3803-3814.
Minichiello L, Casagranda F, Tatche RS, Stucky CL, Postigo A, Lewin GR, Davies AM, Klein R (1998) Point mutation in trkB causes loss of NT4dependent neurons without major effects on diverse BDNF responses. Neuron 21:335-345.

Minichiello L, Korte M, Wolfer D, Kühn R, Unsicker K, Cestari V, RossiArnaud C, Lipp HP, Bonhoeffer T, Klein R (1999) Essential role for TrkB receptors in hippocampus-mediated learning. Neuron 24:401-414.

Minichiello L, Calella AM, Medina DL, Bonhoeffer T, Klein R, Korte M (2002) Mechanism of TrkB-mediated hippocampal long-term potentiation. Neuron 36:121-137.

Miyamoto Y, Chen L, Sato M, Sokabe M, Nabeshima T, Pawson T, Sakai R, Mori N (2005) Hippocampal synaptic modulation by the phosphotyrosine adapter protein $\mathrm{ShcC} / \mathrm{N}-\mathrm{Shc}$ via interaction with the NMDA receptor. J Neurosci 25:1826-1835.

Nagy A, Delgado-Escueta AV (1984) Rapid preparation of synaptosomes from mammalian brain using nontoxic isoosmotic gradient material (Percoll). J Neurochem 43:1114-1123.

Olton DS, Walker JA, Gage FH (1978) Hippocampal connections and spatial discrimination. Brain Res 139:295-308.

Ou LC, Gean PW (2006) Regulation of amygdala-dependent learning by brain-derived neurotrophic factor is mediated by extracellular signalregulated kinase and phosphatidylinositol-3-kinase. Neuropsychopharmacology 31:287-296.

Paré D, Quirk GJ, Ledoux JE (2004) New vistas on amygdala networks in conditioned fear. J Neurophysiol 92:1-9.

Phillips RG, LeDoux JE (1992) Differential contribution of amygdala and hippocampus to cued and contextual fear conditioning. Behav Neurosci 106:274-285.

Postigo A, Calella AM, Fritzsch B, Knipper M, Katz D, Eilers A, Schimmang T, Lewin GR, Klein R, Minichiello L (2002) Distinct requirements for TrkB and TrkC signaling in target innervation by sensory neurons. Genes Dev 16:633-645.

Rattiner LM, Davis M, French CT, Ressler KJ (2004) Brain-derived neurotrophic factor and tyrosine kinase receptor B involvement in amygdaladependent fear conditioning. J Neurosci 24:4796-4806.

Rodrigues SM, Schafe GE, LeDoux JE (2004a) Molecular mechanisms underlying emotional learning and memory in the lateral amygdala. Neuron 44:75-91.

Rodrigues SM, Farb CR, Bauer EP, LeDoux JE, Schafe GE (2004b) Pavlovian fear conditioning regulates Thr286 autophosphorylation of $\mathrm{Ca}^{2+}$ / calmodulin-dependent protein kinase II at lateral amygdala synapses. J Neurosci 24:3281-3288.

Rogan MT, Stäubli UV, LeDoux JE (1997) Fear conditioning induces associative long-term potentiation in the amygdala. Nature 390:604-607.

Romanski LM, LeDoux JE (1992) Equipotentiality of thalamo-amygdala and thalamo-cortico-amygdala circuits in auditory fear conditioning. J Neurosci 12:4501-4509.

Rossi-Arnaud C, Ammassari-Teule M (1998) What do comparative studies of inbread mice add to current investigations on the neural basis of spatial behaviors? Exp Brain Res 123:36-44.

Schafe GE, Nader K, Blair HT, LeDoux JE (2001) Memory consolidation of pavlovian fear conditioning: a cellular and molecular perspective. Trends Neurosci 24:540-546.

Swanson LW, Petrovich GD (1998) What is the amygdala? Trends Neurosci 21:323-331.

Weisskopf MG, Bauer EP, LeDoux JE (1999) L-type voltage-gated calcium channels mediate NMDA-independent associative long-term potentiation at thalamic input synapses to the amygdala. J Neurosci 19:10512-10519.

Xu B, Gottschalk W, Chow A, Wilson RI, Schnell E, Zang K, Wang D, Nicoll RA, Lu B, Reichardt LF (2000) The role of brain-derived neurotrophic factor receptors in the mature hippocampus: modulation of long-term potentiation through a presynaptic mechanism involving TrkB. J Neurosci 20: $6888-6897$. 